九州大学学術情報リポジトリ

Kyushu University Institutional Repository

\title{
SYSTEMATIC STUDIES ON THE GENUS PALAEORHIZA OF NEW GUINEA COLLECTED BY THE THIRD ARCHhOLD EXPEDITION (II) (HYMENOPTERA, COLLETIDAE)
}

Hirashima, Yoshihiro

Lieftinck, M. A.

https://doi.org/10.5109/2439

出版情報: ESAKIA. 20，pp.93-129，1983-12-15. Entomological Laboratory，Faculty of Agriculture， Kyushu University

バージョン：

権利関係 : 


\title{
SYSTEMATIC STUDIES ON THE GENUS PALAEORHIZA OF NEW GUINEA COLLECTED BY THE THIRD ARCHBOLD EXPEDITION (II) (HYMENOPTERA, COLLETIDAE)*
}

\author{
Y OSHIHIRO HIRASHIMA \\ Entomological Laboratory, Faculty of Agricul ture. \\ Kyushu University, Fukuoka 812, Japan \\ and \\ M. A. Lieftinck \\ "Kalliste", 3911 MS Rhenen, The Netherlands
}

\begin{abstract}
Additional 19 species of Palaeorhiza taken by the 3rd Archbold Expedition are reported in this second and final report. Sixteen species are described as new, as follows : polita, bicolorata, subhyalina, trigona, robusta, falcifera, nigra, distincta, gloriosa, paracylindrica, punctata, capitata, aenea, nana, viridiceps and subcrassiceps.
\end{abstract}

This is the second and final report on the genus Palaeorhiza Perkins of New Guinea taken by the 3rd Archbold Expedition. This paper reports 19 species, 16 of which are described as new.

Thus, the total number of species of Palaeorhiza taken by the 3rd Archbold Expedition is 44 .

The subgeneric classification of the 19 species reported in this paper is not attempted. Although they are very diverse in form and color, the morphological distinction is obscure. However, they are probably divisible into several subgenera eventually.

KEY TO THE SPECIES TREATED IN THIS PAPER

1. Head and thorax black, not metallic, with or without yellow markings $\ldots \ldots \ldots \ldots \ldots \ldots \ldots 2$

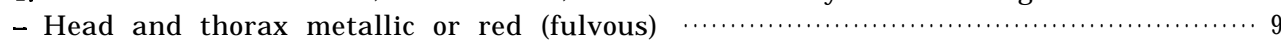

2. Small species, length about $6 \mathrm{~mm}$; head and thorax black with rich yellow markings in both sexes; legs and metasoma red ; mesoscutum somewhat strongly,

* Contribution from the Entomological Laboratory, Faculty of Agriculture, Kyushu University, Fukuoka (Ser. 3, No. 135). 
sparsely punctate on smooth, shining ground; scutellum, metanotum and basal portion of propodeal enclosure flat; hairs on apical portion of metasoma brown

polita, new species

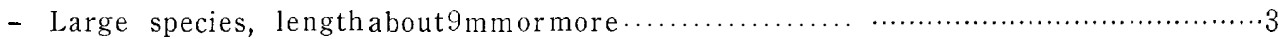

3. Legs and metasoma red, or at least 1 st metasomal segment red $\ldots \ldots \ldots \ldots \ldots \ldots \ldots \ldots \ldots \ldots$

- Metasoma entirely black, with or without metallic tint ................................ 7

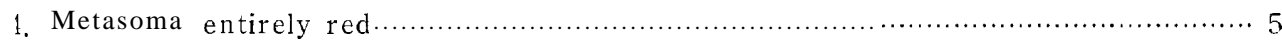

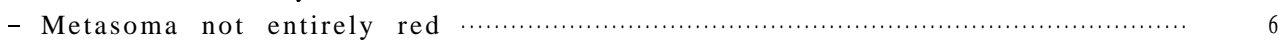

5. Female: length about $9 \mathrm{~mm}$; head and thorax shining black, without yellow marking; malar space about half as long as basal width of mandible in the middle, narrowed anteriorly; mesoscutum rather densely, somewhat strongly punctate ; scutellum well convex ; metanotum also slightly convex ; covering hairs on propodeum pale fulvous; wings distinctly brownish $\cdots$ bicolorata, new species

- Male: about the same size with the preceding species, and probably very close to it; malar space about as long as basal width of mandible; clypeo-ocular distance also very long; 1st metasomal tergum large, well convex dorsally and laterally; 3rd sternum with a considerably large, lamellate projection in the middle; 5th sternum with apical fringe of long, curled hairs ; covering hairs on propodeum snow-white ; wings subhyaline $\ldots \ldots \ldots \ldots \ldots \ldots \ldots \ldots$ subhyalina, new species

6. Female : length $10-11 \mathrm{~mm}$; head long, with following markings yellow: long stripe along inner eye margin, median stripe on clypeus, round mark on lower portion of supraclypeal area and round mark, which is divided by a brown groove in the middle, on upper portion of supraclypeal area; thorax with interrupted pale yellow band on pronotum only; metasoma with 3 basal segments dark red, 3 apical segments black with slight metallic tint; thorax exceedingly densely punctate, punctures not strong, with rather dense, short, dull white or grey hairs; propodeal enclosure triangular, almost all dorsal, flat, distinctly shagreened, dull; wings strongly brownish ….................... trigona, new species

- Male: large, robust species, length about or slightly less than $12 \mathrm{~mm}$; yellow markings confined to head, as follows: stripe on mandible, round mark on labrum, lateral facial stripe (below antennae), bottle-like long mark on clypeus and evanescent stripe on scape; metasoma with 1st tergum red, shining, 2nd and following terga piceous with metallic (purple and blue-green) tint; malar space slightly shorter than basal width of mandible; mesepisternum with a massive, V-shaped elevation on lower portion ; underside of thorax broadly and deeply excavated, densely covered with rather long, pale fulvous hairs; metasomal sterna distinctly modified …............................... robusta, new species

7. Female: mandible massive, edentate and falciform; malar space about twothirds as long as basal width of mandible; head without yellow marking; thorax with an interrupted pale yellow band on pronotum only; metasoma deep piceous, shining, with slight metallic (purple and blue) tint; length slightly less

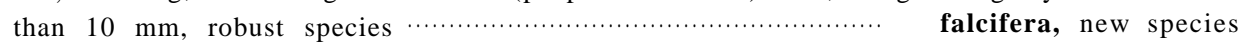

- Mandible as usual, weakly tridentate or nearly so in female . . . . . . . . . . ................... 8

8. Metasoma with blue tint; scutellum well convex; metanotum also distinctly convex medially; mesoscutum rather sparsely, not strongly punctate; hairs on apical portion of metasoma blackish; 3rd sternum of male often with a pair of very large projections

stygica Michener

- Smaller, length about $9 \mathrm{~mm}$; metasoma entirely black, or with slight metallic blue tint; scutellum and metanotum nearly flat; mesoscutum very densely, rather strongly rugoso-punctate; hairs on apical portion of metasoma white; $3 \mathrm{rd}$ and 4 th sterna of male with a pair of weak, rounded, glabrous elevations

nigra, new species 
9. Metasoma metallic, not reddened

- Metasoma entirely red or fulvous, or at least 3 basal segments red …................ 15

10. Male: length about $9 \mathrm{~mm}$, robust; 3 basal metasomal terga with apical broad fringes of dense, white hairs; head and thorax blue with slight greenish tint, with rich ivory markings even on propodeal enclosure; malar space slightly shorter than basal width of mandible ........................... distincta, new species

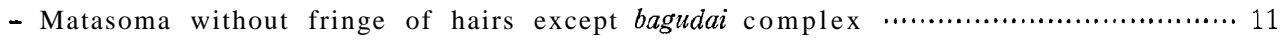

11. Female: robust, length $9 \mathrm{~mm} ; 2$ nd to 4 th metasomal terga with conspicuous yellow markings basally; head and thorax blue-green with rich yellow markings, but yellow marking lacking on median portion of mesoscutum and propodeal enclosure; mesoscutum very densely, rather weakly rugoso-punctate ...

gloriosa, new species

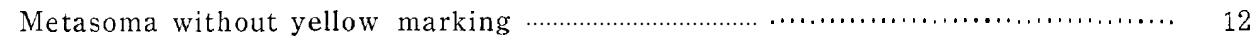

12. Slender, cylindrical species, length about $6 \mathrm{~mm}$; head somewhat globular ; malar space very narrow anteriorly; head and thorax dark blue, with more or less rich yellow markings (markings on thorax somewhat evanescent); meta-

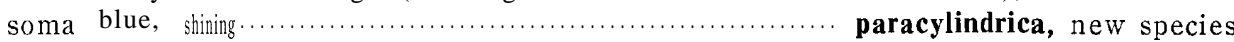

- Not cylindrical, robust species

13. Propodeal enclosure punctate basally, although punctures weak and sparse ; head, thorax and metasoma violet, with slight greenish tint; basal half of $1 \mathrm{st}$ tergum darkened; malar space very narrow anteriorly; hairs on apical portion of metasoma white or silvery; length about $8 \mathrm{~mm} \ldots \ldots \ldots \ldots \ldots \ldots$ punctata, new species

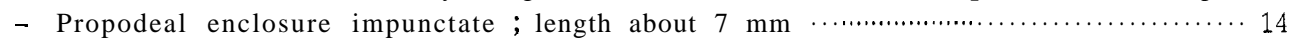

34. Body including legs strongly metallic, but color variable, green, blue-green, or violet; at least 1 st tergum with white hair fringe at side apically; malar space about half as long as basal width of mandible in female, slightly longer in male; mesoscutum strongly, densely rugoso-punctate; punctures on side of thorax also distinct; metasomal terga with broad, impunctate, smooth apical margins conspicuous ; hairs on apical segment of metasoma white ................

bagudai Cheesman complex

- Female: head rather thick; genal area well convex; head and thorax bluegreen, metasoma violet; malar space slightly longer than in bagudai complex; punctures on mesoscutum and scutellum dense and somewhat coarse; metasoma densely punctate until the apex of each tergum, although punctures very fine apically ; hairs on apical portion of metasoma brown …… capitata, new species

15. Body fulvous, including head; pale yellow markings restricted to head only in both sexes; malar space about half as long as basal width of mandible or shorter in female, as long as the latter in male; mesoscutum very densely, rather strongly punctate; metasomal terga with broad, impunctate, smooth apical margins conspicuous ; length about $7.5 \mathrm{~mm}$.............. fulva Cheesman complex

- Head and thorax metallic or at least head alone metallic .......................... 16

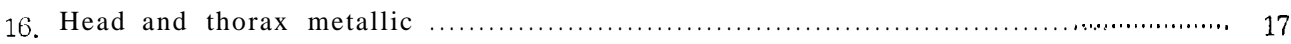

- Head alone metallic; thorax red as in metasoma, with slight to distinct metallic tint on mesoscutum; length about $8 \mathrm{~mm}$

17. Head and thorax blue, with green and purple tint, without yellow marking in female, with a few yellow markings on head alone in male; space slightly shorter than basal width of mandible in both sexes; length about $8 \mathrm{~mm}$

- Male: small species, length slightly over $6 \mathrm{~mm}$; head and thorax blue-green, with rich yellow markings even on propodeal enclosure; however, lower portion of supraclypeal area, frons, metanotum and upper portion of mesepisternum lacking yellow marking ; malar space linear ; eyes large, with inner margins 
strongly converging below; clypeo-ocular distance also very short; scape short, slightly swollen; two basal flagellar segments broader than long, 2nd

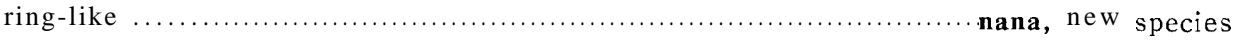

18. Eyes large, with inner margins strongly converging below; space between clypeus and eye narrow, but slightly broader than anterior portion of malar space; the latter very narrow anteriorly, widened posteriorly; ocelli large; ocelloccipital space strongly slanting from just behind ocelli; genal area narrow and strongly receding; mesoscutum densely rugoso-punctate, but punctures rather

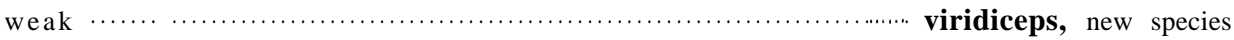

- Eyes moderate or more or less small, with inner margins only slightly converging below; space between clypeus and eye broad, broader than malar space; the latter oblique, about half as long as basal width of mandible in the middle; genal area well developed, convex, thick, scarcely receding below ; ocelli moderate or rather small; space just behind ocelli rather convex, then slanting posteriorly ; mesoscutum densely, strongly rugoso-punctate . . . . . . . .................

subcrassiceps, new species

(26) Palaeorhiza polita, new species

The present material includes 7 females and 1 male from Baliem Camp, in addition to 4 females and 6 males from Wamena, Neth. New Guinea in the collection of Bishop Museum, Honolulu. This is a small, rather robust species having the smooth and shining integument. The coloration of this species is also distinctive as described below.

Female: Length about $6 \mathrm{~mm}$.

Relative head measurements : length, 24.5, width, 26.5; upper interocular distance, 15.0; width of face, 18.0 ; lower interocular distance, slightly less than 12.0; eye length, 19.5; length of clypeus, 10.5 .

Head somewhat rounded in frontal view; vertex well convex; inner eye margins distinctly converging below; mandible bidentate with broad upper tooth; malar space very narrow and almost linear anteriorly, slightly broadened posteriorly ; clypeo-ocular distance short, but longer than malar space ; face distinctly convex ; upper swelling of supraclypeal area rather low, dilated

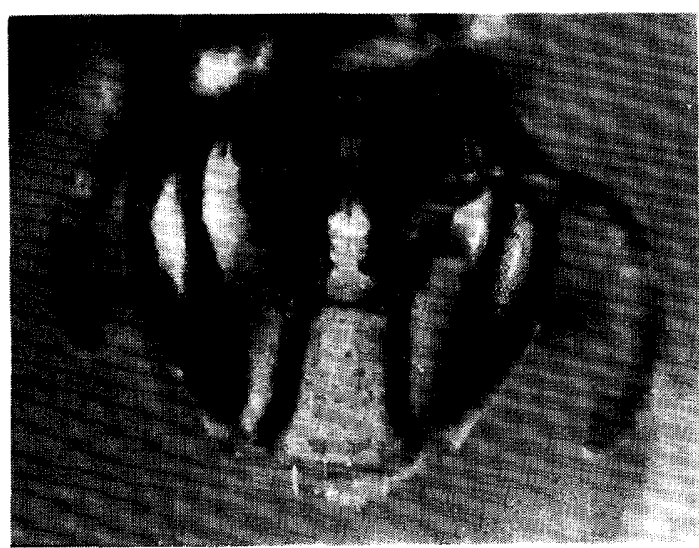

Fig. 34. Palaeorhiza polita, new species. Female head. 
laterally ; frons well convex ; ocelli small ; space behind ocelli strongly slanting. Head nearly smooth, shining in front; clypeus with very weak, longitudinal punctures ; frons largely impunctate except portion near ocelli where weakly punctate.

Collar of pronotum low, thin; mesoscutum somewhat strongly, not densely punctate on polished and shining ground; scutellum large, flat, sculptured like mesoscutum but punctures weaker; metanotum also flat, polished like scutel. lum with minute punctures; propodeal enclosure well convex, smooth, shining, basal portion flat or nearly so ; pre- and meso-episterna like mesoscutum but punctures much weaker; met epist ernum nearly smooth, with microscopical punctures ; lateral face of propodeum finely shagreened anteriorly, with very weak but noticeable punctures posteriorly.

Stigma of fore wing moderate; 2nd submarginal cell well narrowed above, receiving 2nd recurrent vein near end of cell; 1 st recurrent vein interstitial with cubital vein or nearly so.

Legs rather robust, more or less short; fore tarsus slender, with 2nd segment as long as broad, 3rd smaller than 2nd, broader than long, only slightly larger than 4th, which is very small; posterior spur of hind tibia normal.

Metasoma long elliptical ; 1st tergum long; 2nd tergum broadly, moderately convex, very slightly constricted basally; 3rd broadly exposed as usual ; metasomal terga polished, 1st impunctate, 2nd weakly and sparsely punctate, 3rd more punctate than 2 nd.

Head shining black, not metallic, with following markings or portions pale yellow : clypeus except lateral stripe, mandible, labrum, malar space, broad and long mark on paraocular area, broad and long mark on genal area, stripe on supraclypeal area sometimes extending to mid ocellus, and small mark in the middle of ocellocular space ; mouth parts also pale yellow; lower half or more of scape yellowish. Thorax shining black, not metallic, with following markings pale yellow: interrupted band on pronotum, four narrow stripes on mesoscutum (lateral ones often evanescent or disappearing), mark on axilla, lateral stripe of scutellum, more lateral mark on metanotum, tubercle, and three transverse marks on side of thorax below wing bases (two posterior ones often evanescent). Wings slightly brownish; veins and stigma brown or paler. Legs red (pale ferruginous), partly slightly yellowish. Metasoma red, two apical segments sometimes darkened.

Hairs short, sparse, not conspicuous ; hairs on head and thorax white or nearly so; hairs on propodeum including lateral face sparse, not distinct; no tergal hair fringe; hairs on apical portion of metasoma brown or fuscous.

Male: About the same size as female or slightly smaller.

Relative head measurements: length, 24.5; width, 27.0; upper interocular distance, 15.5 ; width of face, 17.5 ; lower interocular distance, 9.5; eye length, 21.0 ; length of clypeus, 10.5 . 


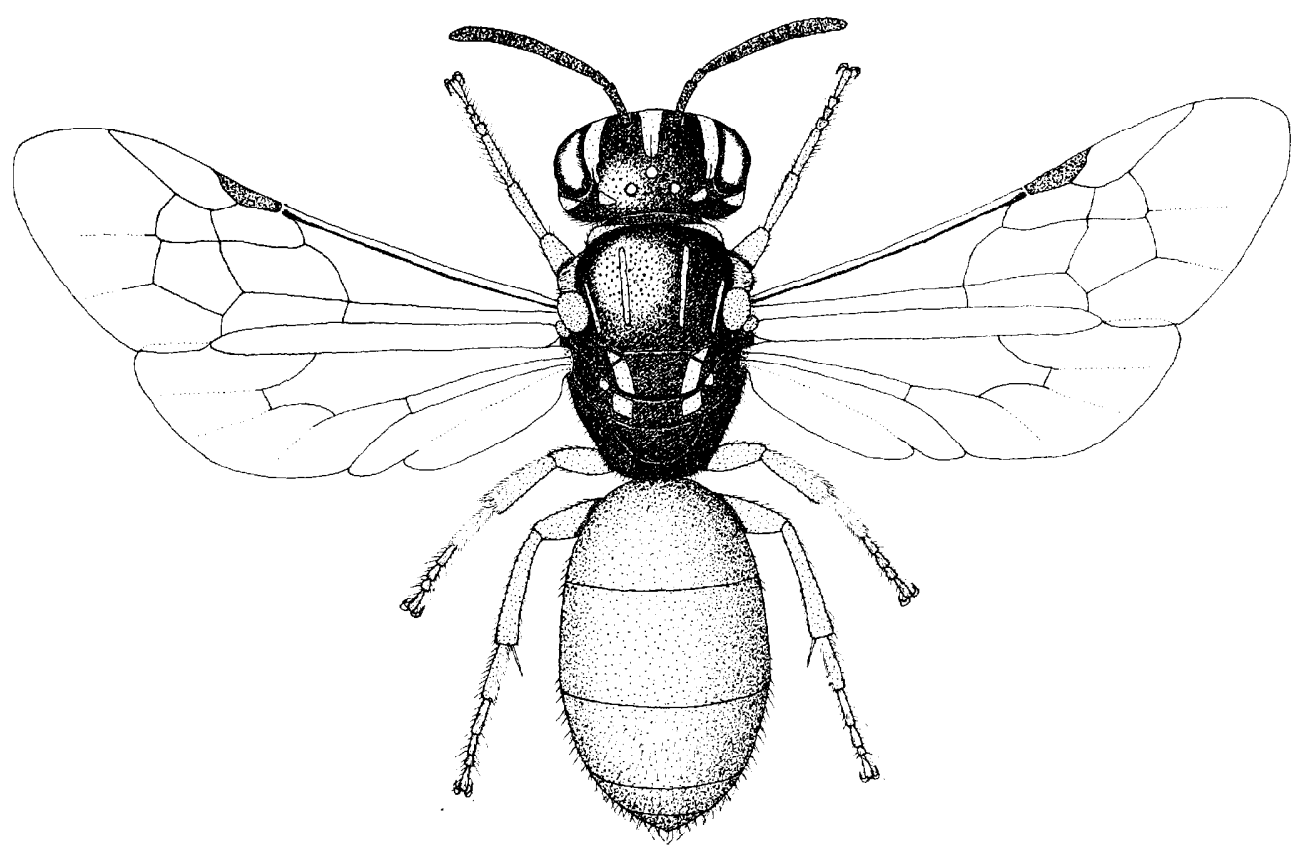

Fig. 35. Palaeorhiza polita, new species, female. (Drawn by S. Naomi).

Agrees with description of female except as follows: head more or less triangular as seen in front; inner eye margins strongly converging below; lower half of face, including clypeus, scarcely convex ; mandible sharply bidentate; scape of antenna rather short, somewhat swollen ; flagellum short, progressively thickened toward apical segment ; flagellar segments broader than long except terminal one; fore tarsal segments longer than in female; 1st tergum long, distinctly convex basally with steep basal face, longer than 2nd ; 3rd sternum with a pair of weak, longitudinal elevations (absent in smaller specimens); no fringe of curled hairs on any apical sterna; genitalia small, not special.

Type material: Holotype female, Baliem Camp, 1,600 m, 2. XII. 1938 (L. J. Toxopeus) ; 6 paratype females, same data as holotype ; 1 paratype male, Baliem Camp, 1,600 m, 19. XI. 1938 (L. J. Toxopeus). Paratypes in Bishop Museum: 4 females and 6 males, Wamena, Neth. New Guinea, 1,700 m,10-25. II. 1960 (T. C. Maa).

Distribution: W. New Guinea.

(27) Palaeqrhiza bicolorata, new species

This is described from a holotype female only. This is a non-metallic, black and red, shining species. Thus, the recognition of this new species is easy. No related species has so far become known. 
Female : Length about $9 \mathrm{~mm}$, with long wings.

Relative head measurements: length, 34.5; width, 40.0; upper interocular distance, 20.0; width of face, 25.5 ; lower interocular distance, 18.5; eye length, 29.0; length of clypeus, 15.0 .

Inner eye margins converging below; mandible weakly tridentate; malar space about half as long as basal width of mandible in the middle, narrowed anteriorly; clypeo-ocular distance slightly longer than nearest part of malar space; median part of face well convex when the head is seen from side; upper swelling of supraclypeal area not strong, only slightly dilated laterally, narrowed and depressed above; frontal region slightly convex; ocelli moderate in size; mid ocellus slightly smaller than lateral one; interocellar distance a little longer than width of lateral ocellus, slightly shorter than ocellocular distance, which is slightly shorter than ocelloccipital distance ; space behind ocelli distinctly slanting.

Collar of pronotum low, not thick, transversely nearly keeled except lateral portion which is slightly rounded ; mesoscutum rather strongly, densely rugosopunctate on nearly smooth, shining ground, punctures slightly larger posteriorly ; scutellum well convex, microscopically tessellate, therefore duller than mesoscutum, with close punctures smaller than those on mesoscutum; metanotum slightly convex, with punctures on the median portion much weaker than those on lateral portion; propodeal enclosure moderately large, microscopically lineolate, not specially shining; pre-episternum with punctures nearly obsolete or with an indication of very weak punctures; upper portion of mesepist ernum with very weak, dense punctures, this sculpture of pre- and meso-episterna considerably weaker than on mesoscutum ; precoxal carina distinct, long; lateral face of propodeum finely shagreened, without distinct punctures.

Stigma of fore wing rather large; 2nd submarginal cell large, distinctly narrowed above, receiving 2nd recurrent veins near end of cell; 1st abscissa

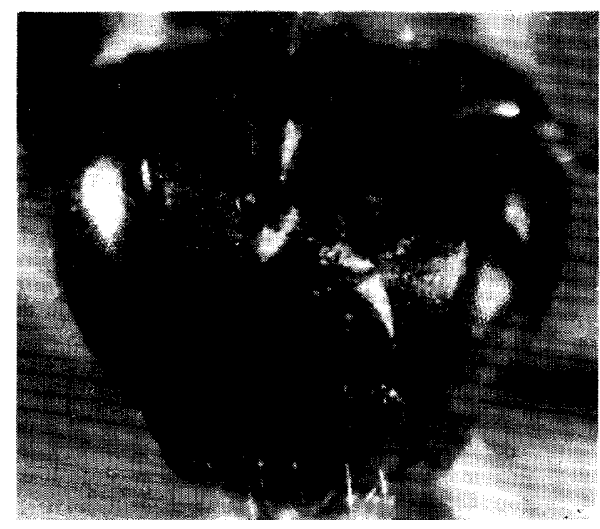

Fig. 36. Palaeorhiza bicolorata, new species. Female head. 
of 2nd submarginal cell about as long as cubital vein.

Legs moderately robust; fore tarsus long, with poor polliniferous hairs; 2nd segment of fore tarsus longer than broad, slightly longer than next segment which is also slightly longer than broad, 4th about as long as broad; hind tibia moderately thick basally, not modified at base ; posterior spur of hind tibia long, unmodified.

Metasoma with 2nd tergum slightly convex medially, slightly constricted basally; metasomal terga shining, rather smooth, with weak, not dense punctures progressively larger toward 3rd tergum; broad, impunctate, smooth posterior margins of three basal terga conspicuous.

Head and thorax shining black, with no yellow marking; tubercles brown ; metasoma and legs red except black or piceous fore coxae, without any darkened portion; wings distinctly brownish ; stigma and veins brown; tegulae brown, shining.

Hairs not conspicuous, yellowish ; hairs on propodeum pale fulvous, rather long and dense dorsally and posteriorly; hairs on legs yellowish or ferruginous; hairs on apex of metasoma fulvous; no tergal fringe of hairs, mixed with brownish ones.

Type material: Holotype female, Mist Camp, 1,800 m, 31. I. 1939 (L. J. Toxopeus) .

Distribution: W. New Guinea.

\section{(28) Palaeorhiza subhyalina, new species}

This is described from the holotype male only. It is probably a close relative of bicolorata, new species. However, the wings of subhyalina are subhyaline with sparser microsetae, while they are distinctly brownish with dense microsetae, as usual, in bicolorata. The covering hairs on the propodeum are snowwhite, while they are pale fulvous in bicolorata.

Male: Length about $9 \mathrm{~mm}$, with long wings, which are subhyaline, with only distal portions slightly darkened.

Relative head measurements : length, 36.5; width, 39.5 ; upper interocular distance, 19.0; width of face, 25.0; lower interocular distance, 19.0 ; eye length, 28.0; length of clypeus, 18.5 ; length of malar space, about 5.5 in the middle; width of mid ocellus, about 3.0.

Head long; inner margins converging below ; mandible bidentate ; malar space conspicuous, about as long as basal width of mandible; clypeo-ocular distance very long, about as long as malar space; clypeus narrow, long, broadly nearly flat; supraclypeal area not well elevated, upper swelling low, rather small, narrowed and depressed above; frons broadly flat; mid ocellus smaller than lateral ocellus; interocellar distance about equal to width of lateral ocellus, shorter than ocellocular distance, which is shorter than ocelloccipital distance; posterior portion of space behind ocelli less slanting than in bicolorata. 


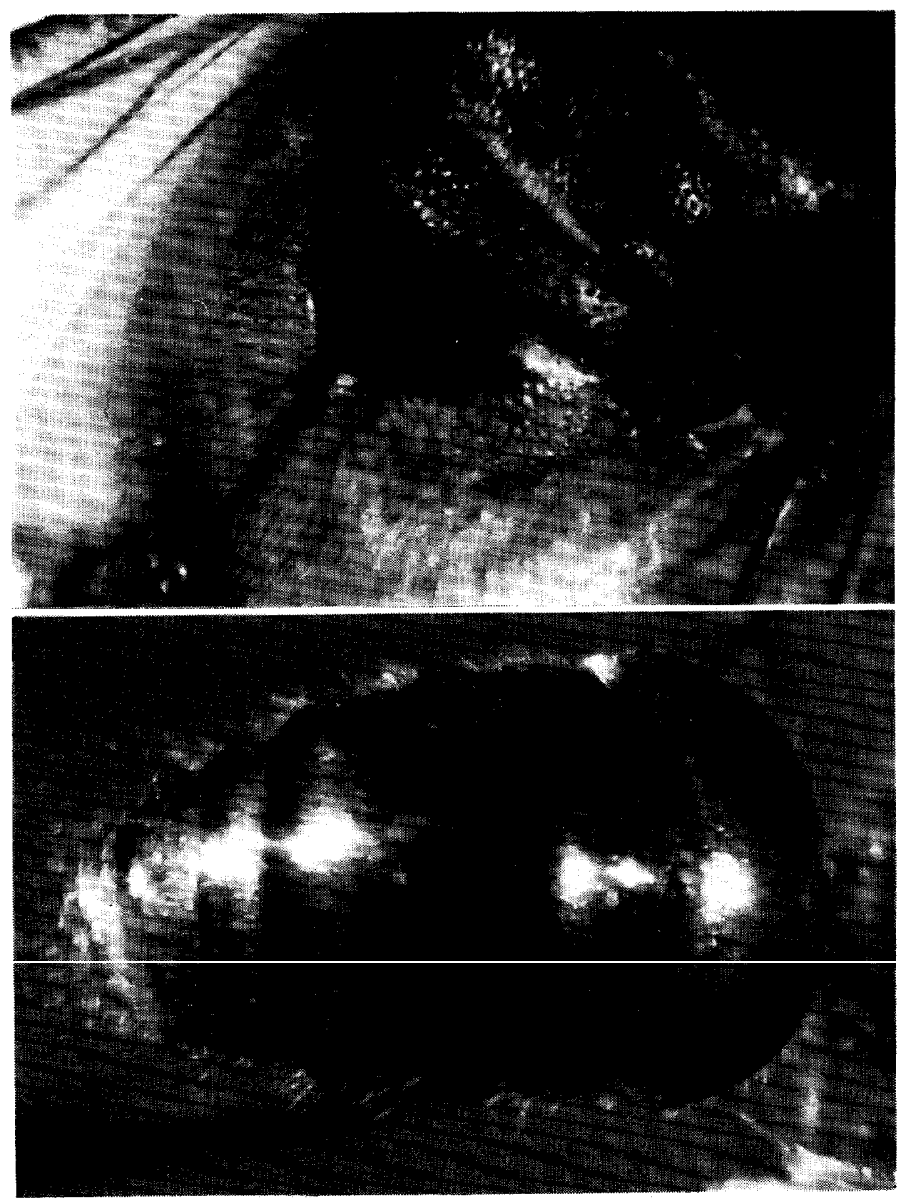

Figs. 37 (above) and 38. Palaeorhiza subhyalina, new species, male, 37: Posterior part of the thorax, dorso-lateral view. 38: Metasoma, dorsal view.

Antennae long; scape rather elongate, about as long as mandible ; flagellum with 1st segment about one and half times as long as broad, about as long as 4th; 2nd a little broader than long or about as long as broad. Face and malar space rather shining; the latter longitudinally, microscopically lineolate ; clypeus microscopically finely tessellate, with irregular punctures apically; supraclypeal area and medio-upper portion of clypeus longitudinally lineolate ; paraocular area longitudinally lineolate, with longitudinal, weak punctures ; frons very finely longitudinally lineolate-punctate ; ocellocular space broadly nearly smooth, shining.

Collar of pronotum low, transversely nearly keeled; mesoscutum well convex, densely and somewhat rugoso-punctate on nearly smooth, shining ground, with punctures weaker than in bicolorata; scutellum weakly bigibbous, somewhat more densely rugoso-punctate than mesoscutum, punctures about as strong as 
those on the latter; metanotum weakly convex, punctate and tessellate; propodeal enclosure more or less small, well defined by absence of punctures and hairs, nearly smooth, shining; pre- and meso-episterna densely but weakly punctate-roughened, punctures much weaker than those on mesoscutum; lower portion of mesepisternum in front of precoxal carina smooth, shining, with coarse, large punctures which are irregular in distribution; underside of thorax deeply concave longitudinally ; lateral face of propodeum shagreened, slightly more roughened than in bicolorata.

Metasoma broadest at 1st tergum; thus, 1st tergum large, well convex, latero-subapical portion well convex outwardly as seen from above; 2nd tergum convex medially, constricted basally and apically; lateral portion of 2nd tergum transversely well convex in the middle; 3rd tergum with a pair of small swellings sublaterally ; 3rd sternum with a very large, transverse, lamellate projection medially, the top of which is deeply emarginate in the middle.

Genitalia small, with slender penis valves distinctly exceeding tip of gonostylus, which is slender, rather acute, with dense hairs on outer face.

Head shining black, lower portion piceous including clypeus, with following markings pale yellow: broad basal stripe on mandible, labrum, a reverse Tmark on clypeus which is evanescent in the middle, small mark on lower paraocular area lateral to malar space, and somewhat evanescent stripe on scape. Flagellum beneath yellowish brown except two basal segments. Thorax black, without yellow marking; tubercles brownish with apical portions narrowly yellowish; tegulae reddish brown, shining. Legs pale yellowish brown except fore coxae brownish; femora, tibiae and tarsi of fore legs broadly, and those of mid legs partly darkened. Metasoma red or brownish red, posterior margins of terga and sterna ferruginous subhyaline; metasoma with no blackened portion except the base of 1st tergum.

Head scanty of hairs; thorax with hairs white; snow-white covering hairs of propodeum, especially those on dorsal and posterior faces, dense and conspicuous (hairs on propodeum pale fulvous in bicolorata); 1st tergum with small fringe of snow-white appressed hairs latero-apically ; 5th sternum with apical fringe of long, curled hairs ; hairs on apical metasomal segments shining pale fulvous, not darkened.

Type materiad: Holotype male, Moss Forest Camp, 2,700 m, 14. X. 1938 (L.

J. Toxopeus).

Distribution: W. New Guinea.

(29) Palaeorhiza trigona, new species

This is described from 6 females. It is another black and red and nonmetallic species, but with yellow stripes on the head and pronotum. The habitus and coloration of the female head recalls that of Heterorhiza. The propodeal enclosure of this species is characteristic, as described below. 
Female: Length $10-11 \mathrm{~mm}$, with long wings,

Relative head measurements : length, 42.0 ; width, 40.5 ; upper interocular distance, 18.5; width of face, 25,0; lower interocular distance, 17.5; eye length, 34.0 ; length of clypeus, 20.5 ; length of malar space, about 3.5 in the middle; width of mid ocellus, 3.5.

Head, as well as face, long; inner eye margins converging below ; malar space distinctive but shorter than basal width of mandible; the latter weakly bidentate, with upper tooth broad and rounded; space between clypeus and eye not broad, narrower than malar space; clypeus long, lateral portions longitudinally elevated; clypeus and most part of supraclypeal area longitudi. nally microscopically lineolat e, with sparse, microscopical and longitudinal punctures; upper portion of supraclypeal area distinctly elevated, upper limit distinct and sharply defined from frons; frontal line distinct, sulcated; frons and paraocular area also very finely sculptured, impunctate ; ocelli large, rather close together; interocellar distance shorter than width of lateral ocellus, which is slightly shorter than ocellocular distance; ocelloccipital distance slightly longer than ocellocular distance, about twice as long as interocellar distance ; space behind ocelli strongly slanting toward preoccipital carina.

Collar of pronotum rather narrow, not highly elevated, with lateral portion rather angulated; mesoscutum and scutellum exceedingly densely, rather strongly punctate, dull; propodeal enclosure triangular, flat, almost all dorsal, densely shagreened, entirely dull ; propodeum outside enclosure coarsely sculptured ; pre- and meso-episterna also very densely rugoso-punctate, hut punctures smaller than those on mesoscutum.

Stigma of fore wing large; 2nd submarginal cell large, slightly shorter than 1st along lower margin; 1st abscissa of 2nd submarginal cell long, about
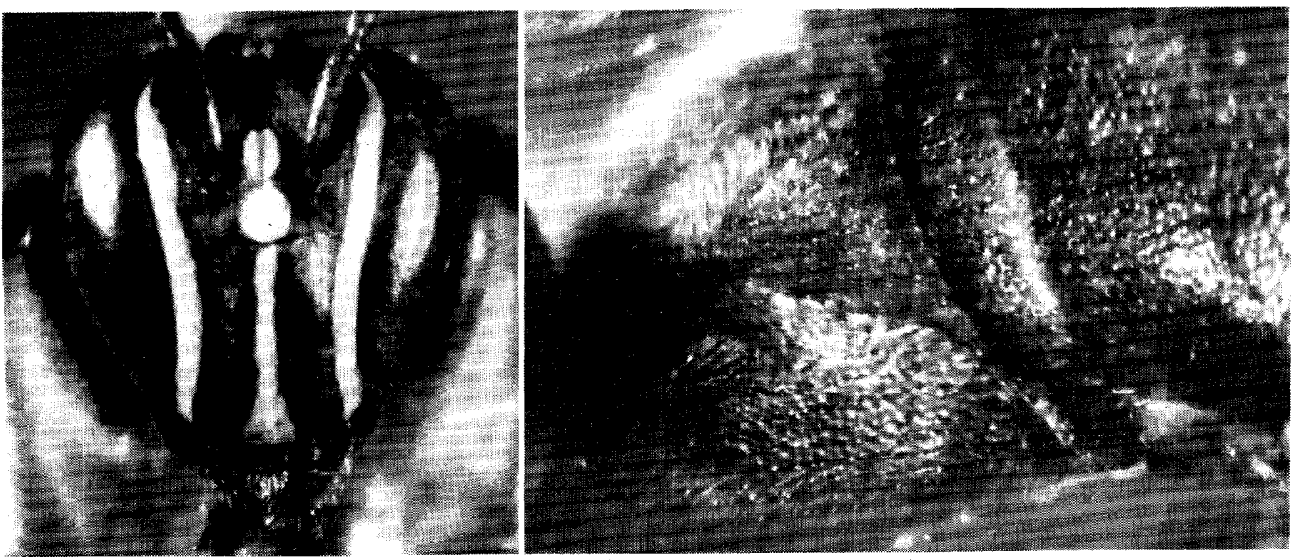

Figs. 39 (left) and 40. Palaeorhiza trigona, new species, female. 39: Head, frontal view. 40: Posterior part of the thorax, dorso-lateral view. Note the characteristic propodeal enclosure, 
as long as cubital vein.

Legs slender ; fore tarsus rather long, with 2nd segment about twice as long as broad, longer and larger than 3rd which is also longer than broad; 4th small and about as long as broad; hind tibia slender, long; posterior spur of hind tibia curved and broadened subbasally, not serrate.

Metasoma long ; 2nd tergum well convex dorsally as usual; metasoma with not strong punctures progressively coarser toward 4th tergum.

Head black, slightly shining, with following markings yellow : median stripe of clypeus, long stripe on paraocular area from base of mandible to facial fovea, round mark on lower portion of supraclypeal area, and divided round mark on upper portion of supraclypeal area. Thorax black, dull, with broadly interrupted pale yellow band on pronotum. Wings distinctly brownish except basal portions paler; veins and stigma fuscous; tegulae brownish subhyaline. Legs piceous with pale yellow markings on fore tibiae. Metasoma with three basal terga and sterna dark red, the remaining terga and sterna black, with slight metallic tint on terga.

Head scanty of hairs; hairs on thorax dull white or grey, with very slight brownish tint ; hairs on mesoscutum very short, fine, inconspicuous ; hairs on propodeum and sides of thorax very short but denser and more conspicuous than those on mesoscutum; metasomal terga without hair fringe ; hairs on three apical segments black.

Type material: Holotype female and 4 paratype females, Sigi Camp, 1,500 m, 24-28. II. 1939 (L. J. Toxopeus) ; paratype female, Lower Mist Camp, 500 m, 28. I. 1939 (L. J. Toxopeus).

Distribution : W. New Guinea.

(30) Palaeorhiza robusta, new species

This is described only from the holotype male. The new species may be a member of the subgenus Cercorhiza Hirashima. It is a very large, robust, black and partly red species, which is very distinctive, as described below. We have seen 2 more male specimens, which represent another new, closely allied species, from Papua New Guinea in the collection of Bishop Museum. For the sake of convenience, the latter is called a Papuan species in the following description,

Male: Robust, slightly less than $12 \mathrm{~mm}$, with long wings.

Relative head measurements : length, 41.0; width, 46.0; upper interocular distance, 22.0; width of face, 26.5; lower interocular distance, 20.0; eye length, 33.0 ; length of clypeus, 20.5; length of malar space, 5.5 ; width of mid ocellus, 3.5.

Eyes large, with inner margins slightly converging below; mandible bidentate, with lower tooth long, broad; malar space long, oblique, only slightly shorter than basal width' of mandible; clypeo-ocular distance long, slightly 


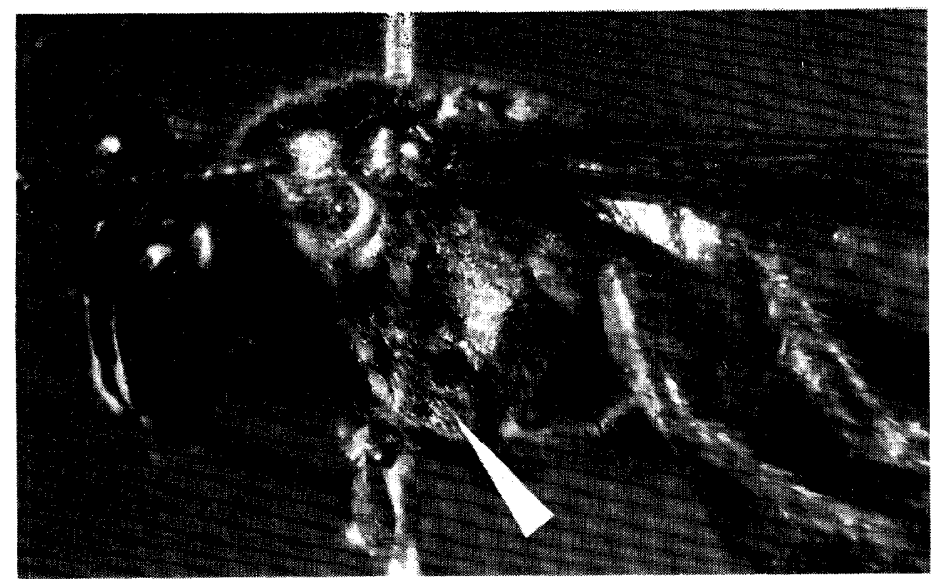

Fig. 41. Palaeorhiza robusta, new species, male. Head and thorax, lateral view. An arrow indicates the elevated disc on the mesepisternum.

shorter than malar space; clypeus broadly flat above; supraclypeal area weakly convex, upper swelling rather small, narrow, with rather sharp edges (this swelling more distinct and dilated laterally in a Papuan species) ; ocelli close together; mid ocellus distinctly smaller than lateral ocellus ; interocellar distance shorter than width of lateral ocellus; ocellocular distance twice as long as interocellar distance, about equal to or a little shorter than ocelloccipital distance; vertex not convex, slightly below a line tangential to summits of eyes as seen in front ; ocellocular space somewhat concave ; ocelloccipital space subhorizontal ; genal area receding.

Thorax massive ; collar of pronotum low, very thin in the middle ; mesoscuturn microscopically tessellate, not distinctly shining, densely rugoso-punctate, but punctures weak and small for the size of insect; scutellum punctate like mesoscutum; median portion of scutellum not depressed, lateral portion of scutellum weakly convex (scutellum somewhat bigibbous in a Papuan species) ; lateral portion of metanotum also weakly convex; this swelling slightly more distinct than that of mesoscutum; median portion of metanotum depressed, flat; propodeal enclosure rather large, almost all dorsal (apex only on posterior face), median portion rather distinctly concave subapically ; lower portion of mesepisternum with a massive, well elevated, V-shaped disc, lateral margins of it smooth, highly shining; upper portion of mesepisternum very weakly rugoso-punctate ; lateral face of propodeum finely shagreened; underside of thorax very deeply and broadly concave.

Stigma of fore wing rather slender; 2nd submarginal cell large, well narrowed above, receiving 2nd recurrent vein near end of cell; 1st abscissa of 2nd submarginal cell slightly shorter than cubital vein.

Legs long, rather robust; hind tibia with an indication of raised, punctate disc at base dorsally. 
Metasoma long, robust; 1st tergum largest, distinctly convex, with basal face steep (1st tergum smaller in a Papuan species) ; 2nd tergum less broadly exposed than 1st, well convex medially, with weak transverse swelling sublaterally; apical margin of 2nd tergum broadly produced apically in the middle; 1st sternum large, long, well convex, broadly covering base of 2nd sternum; 2nd sternum with median portion pale ferruginous subhyaline, broadly flat or slightly concave, lateral portion with a large, somewhat elongate, round swelling which is blackish, smooth, and shining; 3rd sternum with median portion black and broadly more distinctly concave; 3rd sternum with an inner pair of weak, longitudinal swellings and an outer pair of large, distinctly elevated, polished swellings, which are stronger than the corresponding ones of 2nd; basal portion of 4th with a considerably large, strong, polished swelling medially (this swelling smaller and weaker in a Papuan species); the same sternum with small, polished swelling on each side; 5th sternum with fringe of long, curled, fuscous hairs apically. First tergum smooth, strongly shining, with weak, sparse punctures (1st tergum densely and distinctly punctate in a Papuan species) ; 2nd tergum more punctate than 1st, but punctures sparse in the middle (more distinctly and densely punctate in a Papuan species) ; 3rd tergum shagreened with an indication of very weak punctures (densely and more strongly punctate than 3rd in a Papuan species) ; 4th similar to 3rd.

Genitalia small; penis valves slender, slightly exceeding tip of gonostylus, which is hairy, acuminate.

Head shining black with following markings pale yellow: a reverse T-like (or bottle-shaped) mark on clypeus, stripe on paraocular area below antenna, stripe on mandible, large mark on labrum, and evanescent stripe on scape; thorax without yellow marking. Legs reddish, variegated with yellow and brown; coxae and trochanters of all legs piceous or paler. First tergum red; 2nd tergum piceous with brassy and purple tints, partly reddened ; 3rd and following terga piceous with metallic (purple and dark blue-green) tint; sterna red basally, piceous apically. Wings distinctly brownish; veins and stigma fuscous; tegulae brownish, paler and subhyaline anteriorly.

Hairs on head brown, slightly paler on face ; hairs on mesoscutum and scutellum also brownish; hairs on the rest of thorax pale fulvous ; covering hairs on propodeum distinct, rather long, dense; underside of thorax with dense covering of long, subappressed, pale fulvous hairs; metasoma with hairs pale or whitish on basal segments, fuscous or black on apical segments; no tergal hair fringe.

Type material: Holotype male, Mist Camp, 1,800 m, 10. I. 1939 (L. J. Toxopeus).

Distribution: W. New Guinea. 


\section{(31) Palaeorhiza falcifera, new species}

This is described from the holotype female only. The female of this species is unique in having a broad, edentate, falciform mandible, a feature similar to that of Anchirhiza. In addition, this interesting species is easily recognizable by the following characters: body entirely black with a faint metallic tint on metasoma only and with an interrupted yellow band on pronotum only.

Female: Length slightly less than $10 \mathrm{~mm}$, with long wings.

Relative head measurements: length, from vertex to apex of clypeus, which is emarginate in this species, 46.0; width, 45.5; upper interocular distance, 24.0; width of face, 29.5; lower interocular distance, 22.0; eye length, 30.0; length of clypeus, 16.0 ; length of malar space, 4.0 ; width of mid ocellus, 3.5 .

Inner eye margins distinctly converging below; eyes more or less small; malar space long, about two-thirds as long as basal width of mandible; mandible massive, edentate, falciform with sharp edge; unlike Anchirhiza, outer face of mandible well convex and coarsely sculptured; process of labrum distinctly tuberculate; apical margin of clypeus thickened, emarginate ; dypeus with midapical portion depressed; distance between clypeus and eye long, about as long as or a little longer than malar space; upper swelling of supraclypeal area well convex, weakly dilated laterally, slanting and lowered above, upper limit not sharply defined from frons ; ocelli more or less small ; interocellar distance a little longer than diameter of lateral ocellus, about half as long as ocellocular distance; the latter about as long as ocelloccipital distance. Clypeus and paraocular area lateral to clypeus densely, strongly and rather coarsely punctate on minutely shagreened and slightly shining ground; punctures on frons weak, considerably weaker than those on clypeus; space between eye and ocellus smooth, shining, with sparse punctures; genal area rather broad, rather well

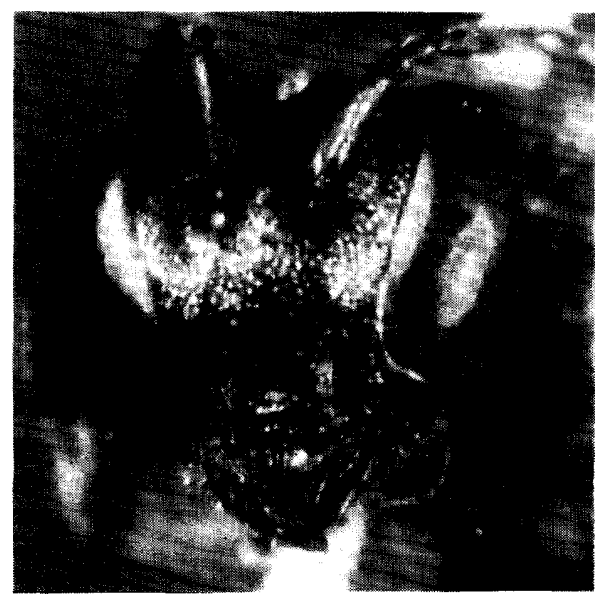

Fig. 42. Palaeorhiza falcifera, new species, female. Frontal (slightly oblique) view of the head. Note the edentate and falciform mandible. 
developed.

Thorax well convex dorsally; mesoscutum rather coarsely and strongly punctate on nearly smooth and shining ground ; scutellum broadly, weakly convex ; broad metanotum also weakly convex ; propodeal enclosure large, slanting, nearly smooth and shining except basal portion minutely shagreened; mesepisternum microscopically shagreened, dull, with strong, coarse punctures ; punctures on mesepisternum sparser but about as strong as or slightly stronger than those on mesoscutum. Wings distinctly brownish except basal portion subhyaline; veins and stigma fuscous; the latter more or less slender; 2nd submarginal cell large, subquadrate, 1 st abscissa about half as long as cubital vein. Legs slender; fore tarsus with 2 nd segment slightly longer than broad, subequal to or a little larger than 3rd, which is larger than 4th; hind tibia slender; posterior spur of hind tibia normal, finely ciliate.

Metasoma distinctly convex dorsally, almost elliptical as seen from above; metasomal terga, especially two basal ones, nearly smooth, shining, with very sparse, weak punctures ; 3rd tergum transversely, microscopically lineolate, with sparse, shallow, somewhat large punctures.

Head and thorax black; collar of pronotum with an interrupted, narrow, yellow, band ; no other pale marking on head and thorax; metasoma black or piceous, with a faint metallic blue-purple reflection. Legs piceous. Wings distinctly brownish except basal portions subhyaline; veins and stigma fuscous; tegulae fuscous.

Not specially hairy ; hairs on vertex and face fuscous, those on apical portion of clypeus and on mandible paler and whitish; hairs on thorax white; mesoscutum and scutellum intermixed with sparse, fuscous hairs ; hairs on legs primarily white ; metasomal terga without fringe of hairs; hairs on apex of metasoma fuscous.

type materiat: Holotype female, Top Camp, 2,100 m, 4. II. 1939 (L. J. Toxopeus).

Distribution: W. New Guinea.

(32) Palaeorhiza stygica Michener

Palaeorhiza (Palaeorhiza) stygica Mich en er, 1965, Bull. Amer. Mus. Nat. Hist., 130: 302. Female and male.

The type locality of this interesting species is 6 miles north of Nondugl, Western Highlands District, Papua New Guinea. This is the first record of this species from western New Guinea. The present material includes 2 female and 10 male specimens. In one female specimen, the clypeus and space lateral to it are nearly smooth and therefore much more shining than in Papuan stygica.

It is very interesting to note the morphological variation of the male. In 

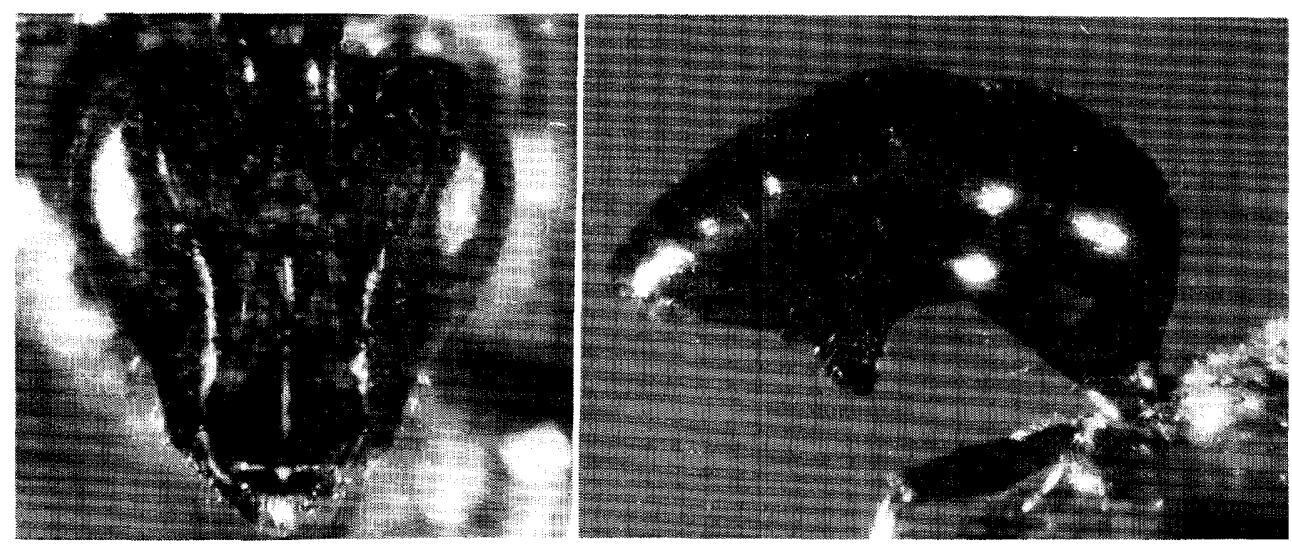

Figs. 43 (left) and 44. Palaeorhiza stygica Michener, male. 43: Head, frontal view, 44: Metasoma, lateral view. Note the projection on the 3rd sternum.

4 specimens out of 10 , the 3 rd sternum is unmodified. These specimens seem to be only slightly smaller than others which are provided with a pair of huge conical projections on the 3rd sternum as noted in the original description.

Specimens examined: 1 female and 6 males, Ibele Camp, 2,250 m, XI-XII. 1938 (L. J. Toxopeus) ; 1 female and 4 males, Top Camp, 2, 100 m, 21. I. 1939 (L. J. Toxopeus).

Distribution : New Guinea.

\section{(33) Palaeorhiza nigra, new species}

This is described from 8 females and 2 males. This is another black species of Palaeorhiza, related to $P$. falcifera or stygica so far as the coloration is concerned, but is distinguished in having the normal mandible, the flat metanoturn (convex in the middle in stygica) and the silvery hairs on the apex of metasoma (hairs black or nearly so in stygica and falcifera).

Female: More or less slender, length slightly less than $10 \mathrm{~mm}$, with long wings.

Relative head measurements : length, 34.0; width, 38.0 ; upper interocular distance, 22.5 ; width of face, 26.0 ; lower interocular distance, 21.0 ; eye length, 26.0 ; length of clypeus, 16.0 ; length of malar space, 4.0 ; width of mid ocellus, 3. 5 .

Inner eye margins slightly converging below; face well convex ; clypeus broadly flat, microscopically tessellate or lineolate, therefore duller than in stygica, with very weak and sparse punctures ; malar space long and distinctive, but shorter than basal width of mandible; mandible as usual, bidentate with upper tooth broad, rounded; space between clypeus and eye about as broad as malar space ; supraclypeal area well convex in the middle, upper swelling dilated laterally, flattened above, upper limit not sharply defined from frons; 
upper portion of supraclypeal area less dilated laterally and less convex than in stygica; paraocular area lateral to clypeus more coarsely sculptured than clypeus, usually well punctate ; frons and vertex shagreened-punctate, duller; ocelli small ; ocellocular distance about one and half times as long as interocellar distance, slightly longer than ocelloccripital distance.

Thorax comparatively narrower and longer than in stygica; mesoscutum well convex, very densely, rather strongly rugoso-punctate, interspaces narrower than a puncture width; thus, mesoscutum much more densely punctate than in stygica ; scutellum large, flat; metanotum also flat, with weaker punc. tures ; propodeal enclosure large, well convex, slanting, nearly smooth or microscopically lineolate, shining; mesepisternum sculptured like mesoscutum but punctures weaker.

Wings with stigma moderate or rather small; 2nd submarginal cell with 3rd abscissa about as long as or slightly shorter than 1st abscissa, which is about half as long as cubital vein.

Legs with 2nd segment of fore tarsus slightly longer than broad, slightly larger than 3rd which is also larger than 4th; hind tibia slender ; posterior spur of hind tibia normal.

Second metasomal tergum distinctly convex in the middle; metasoma well punctate, with punctures progressively coarser toward 4th tergum; apical broad impunctate margins well marked on 2nd to 4th terga.

Body and appendages black, with no pale marking on any part of body except for occasional pale stripe on inner basal portion of fore tibia; metasoma sometimes with very faint bluish tint, with or without purple reflection. Wings distinctly brownish, paler basally (wings slightly paler than in stygica) ; veins and stigma fuscous; tegulae also fuscous.

Hairs sparse, not conspicuous, white or silvery including those on apex of metasoma.

Male : Slightly smaller than female.

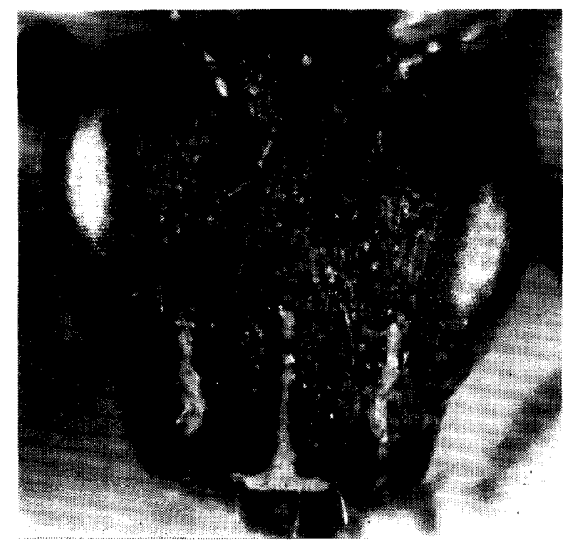

Fig. 45. Palaeorhiza nigra, new species. Male head in frontal view. 
Relative head measurements : length, 35.0; width, 37.5 ; upper interocular distance, 21.0; width of face, 23.0; lower inter-ocular distance, 18.0; eye length, 27.5 ; length of clypeus, 16.0 ; length of malar space, 5.0 ; width of mid ocellus, 3.5 .

Agrees with description of female except as follows: malar space about as long as basal width of mandible ; head with following markings pale yellow: a reverse T-mark on clypeus, stripe on paraocular area lateral to clypeus, basal stripe on mandible (in one specimen it is evanescent), and a spot on labrum, which is not present in one specimen. Third 'and 4th sterna each with a pair of large, glabrous, weak swellings in the middle; 5 th sternum with curled fringe of long, brown-silvery hairs apically ; this fringe of hairs less conspicuous than in stygica; unlike stygica, hairs on apical portion of metasoma silvery.

Type materias: Holotype female, 7 paratype females and 2 paratype males, Lake Habbema, 3, 250 3,300 m, VIII. 1938 (L. J. Toxopeus).

Distribution: W. New guinea.

\section{(34) Palaeorhiza distincta, new species}

This is described after the holotype male from Bernhard Camp. It is not in a good condition, unfortunately. This is a robust, metallic species having rich ivory markings on the head and thorax and white hair bands on 3 basal terga.

Male: Length about $8.5 \mathrm{~mm}$.

Head rather long and more or less thick; eyes slender, with inner margins only slightly converging below; mandible subfalciform, nearly simple or weakly bidentate; malar space slightly shorter than basal width of mandible; clypeo-ocular distance also long ; supraclypeal area well convex, upper swelling rather narrow ; ocelloccipital space subhorizontal, only posterior portion slightly slanting; genal area well convex just behind eye, especially on upper portion. Antennae with scape elongate, slightly longer than four basal segments of flagellum taken together; flagellum long, with 1st segment about as long as broad, slightly longer than 2nd which is much broader than long, 3rd longer than broad, shorter than 1st and 2nd combined.

Collar of pronotum rather thick, well convex dorsally; mesoscutum strongly, densely rugoso-punctate on smooth, shining ground; scutellum more strongly, more sparsely punctate than posterior portion of mesoscutum; propodeal enclosure rather short, well convex, nearly smooth, shining, apical portion on vertical posterior face ; pre- and meso-episterna distinctly punctate, but punctures much weaker than those on mesoscutum; precoxal carina conspicuous.

Metasoma robust; 1st tergum large, long, well convex basally, basal face steep; 2nd tergum constricted basally; 7th tergum with a pair of rather widely separated projections apically; sterna unmodified; 2nd sternum broadly flat medially and broadly exposed. 


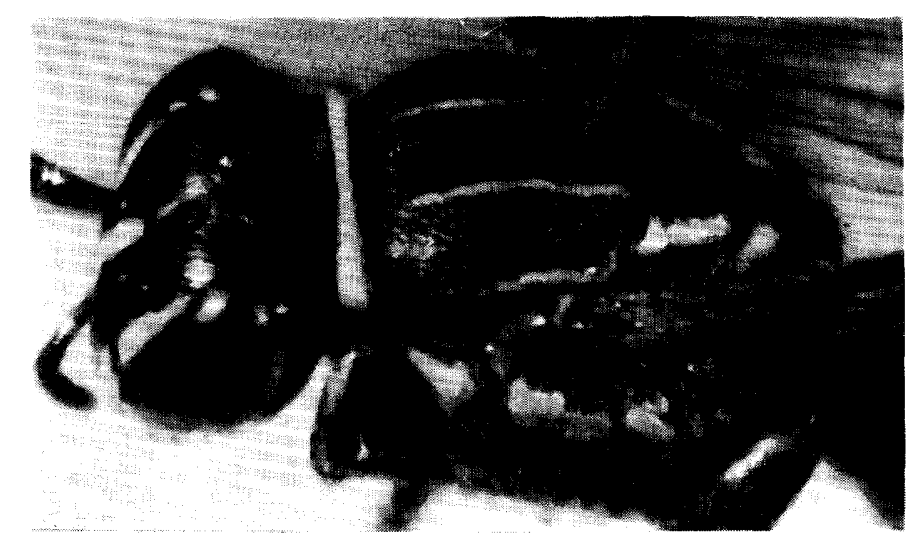

Fig. 46. Palaeorhiza distincta, new species, male. Dorso-lateral view of the head and thorax.

Head and thorax shining steel-blue with slight greenish tint on frons and thorax dorsally, with following markings or portions ivory: 3 long stripes on face (the median stripe broadened on apex of clypeus, and very narrow on frons above supraclypeal area), slender stripe on genal area along eye margin, large round mark on labrum (pale yellow), entire band on pronotum, 4 longitudinal stripes on mesoscutum (lateral ones short), triangular mark on axilla, lateral stripe on scutellum, a pair of large transverse marks on metanotum, a pair of slender, posteriorly converging stripes on propodeal enclosure, large mark on tubercle, and 3 transverse marks on side of thorax just below wing bases. Legs piceous with steel-blue and purple tints, and with pale yellow markings on tibiae of fore and mid legs (posterior legs missing). Wings distinctly brownish. Metasoma shining, distinctly blue dorsally, piceous ventrally.

Hairs in poor condition; hairs on propodeum dull white; apical margins of 3 basal terga with broad, white hair bands, which are lateral on Ist, more developed on 2nd and nearly complete on 3rd; 4th and following sterna with long, fuscous, somewhat curled hairs.

Type material: Holotype male, Mountain slope above Bernhard Camp, 750 m, 19. III. 1939 (L. J. Toxopeus).

Distribution: W. New Guinea.

(35) Palaeorhiza gloriosa, new species

This is described from the holotype female only. It is a metallic and decorative species whose metasoma is also decorated with large yellow markings. No related species is known to us.

Female : Robust, length about $9 \mathrm{~mm}$, with short wings.

Relative head measurements : length, 36.0; width, 38.0; upper interocular distance, 19.0; width of face, 24.0; lower interocular distance, 18.5; eye 
length, 29.0; length of clypeus, 14.5 .

Inner eye margins slightly converging below; malar space narrow anteriorly, widened posteriorly, less than half as long as basal width of mandible in the middle; space between clypeus and eye' much broader than nearest part of malar space; clypeus and supraclypeal ar'ea well convex, upper swelling not highly elevated, lowest above, with median' sulcus distinct; ocelli moderate in size, rather broadly separated from each other; interocellar distance slightly shorter than ocellocular distance (about $4: 5$ ); the latter about equal to ocelloccipital distance. Clypeus with punctures weak, somewhat roughened ; paraocular area finely lineolate-punctate; frons and vertex very densely punctate, punctures small.

Collar of pronotum thick, well convex, its outline arched as seen in front; mesoscutum and scutellum very densely rugoso-punctate, punctures small ; metanotum nearly flat or only slightly convex; propodeal enclosure rather short, more or less small, slightly depressed in the middle basally; surface of enclosure microscopically lineolate, slightly shining; pre- and meso-episterna

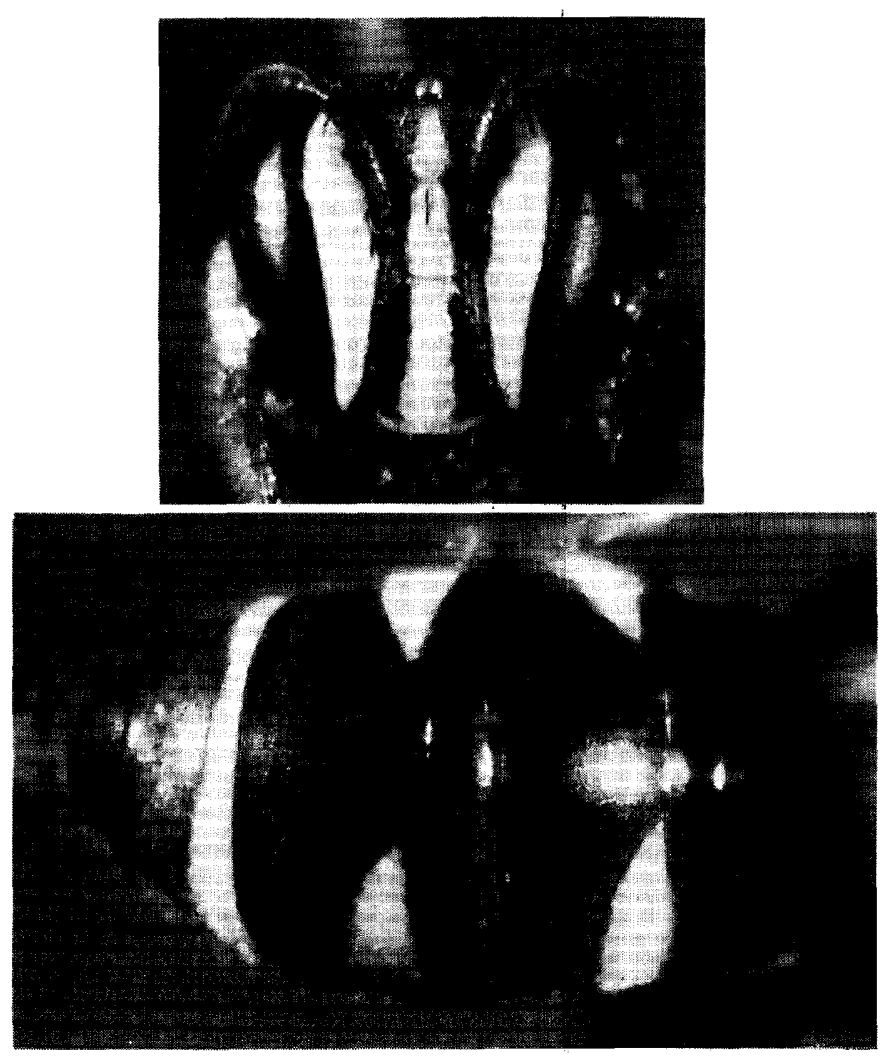

Figs. 47 (above) and 48. Palaeorhiza gloriosa, new species, female. 47: Head, frontal view. 48: Metasoma, dorsal view. 
exceedingly densely punctate, punctures much smaller than those on mesoscuturn, slightly stronger than those on frons.

Stigma of fore wing moderate in size; 2nd submarginal cell narrowed above, with 1st abscissa about half as long as cubital vein.

Legs robust; 2nd segment of fore tarsus about as long as broad, only slightly larger than 3rd; hind tibia robust, short, not modified at base dorsally ; posterior spur of hind tibia unmodified.

Metasoma with 2nd tergum not specially convex in the middle; metasomal terga without distinct punctures, only with an indication of microscopically fine, close punctures.

Head and thorax metallic blue-green, with rich yellow markings or spaces, as follows: 3 broad and long stripes on face, long broad mark on genal area along eye margin, entire band on collar of pronotum, broad stripe along lateral margins of mesoscutum, axilla, lateral stripe on scutellum, nearly full space of metanotum, tubercle, and 3 quadrate marks behind it (below tegulae); thus, median portion of mesoscutum and propodeal enclosure lacking yellow markings. Wings slightly brownish subhyaline; tegulae pale yellowish brown subhyaline, with yellow spot. Legs brownish red, with large yellow markings on all tibiae. Metasoma piceous (or more reddened) with strong metallic purple and blue (or blue-green) tints; 2nd and 3rd terga with large, pyriform, yellow markings at base laterally; 4th tergum with entire, broad. yellow band basally; 2 basal sterna dark red with purple-blue tint; 3rd to 5th sterna with strong blue-purple tint.

Hairs not conspicuous, short and whitish; hairs on apex of metasoma black.

Type material: Holotype female, Bernhard Camp, $50 \mathrm{~m}$, VII-XI. 1938 (J. Olthof) .

Distribution: w. New Guinea.

\section{(36) Palaeorhiza paracylindrica, new species}

This species is described on the basis of 3 females. Very close to Palaeorhiza cylindrica Hirashima, from Wisselmeren, but differs from it as described below.

Female : Slender and cylindrical, length about $7 \mathrm{~mm}$ or slightly smaller, with long wings.

Relative head measurements : length, 22.0; width, 25.0; upper interocular distance, 14.0; width of face, 17.0; lower interocular distance, 12.0; eye length, 18.0; length of clypeus, about 8.5.

Head round as seen in front; inner eye margins rather distinctly converging below; malar space very narrow anteriorly and widened posteriorly as in cylindrica; as seen from side, head distinctly convex in front, especially portion of frons and supraclypeal area; upper swelling of supraclypeal area narrower and less dilated laterally than in cylindrica; ocelli rather small ; space behind 
ocelli slanting posteriorly. Frons very closely and finely punctate, punctures weaker and finer than in cylindrica.

Thorax distinctly elongate; collar of pronotum thin, concave medially as cylindrica; mesoscutum very closely and finely punctate, a feature similar to frons, and punctures weaker than in cylindrica; scutellum and metanotum flat; propodeum long with long enclosure slightly more slanting than in cylindrica, nearly smooth, shining; sides of thorax less coarsely sculptured than in cylindrica with weaker (very small) punctures; lateral face of propodeum finely shagreened with covering of dull short white hairs similar to cylindrica.

Wings with stigma moderately large ; 1st recurrent vein coinciding with cubital vein, or nearly so.

Legs more or less slender; fore tarsus short, 2nd segment broader than long, about as large as 3rd, which is larger than 4th; hind tibia not modified at base, posterior spur normal.

Metasoma cylindrical ; 1st tergum long, well convex basally; 2nd weakly
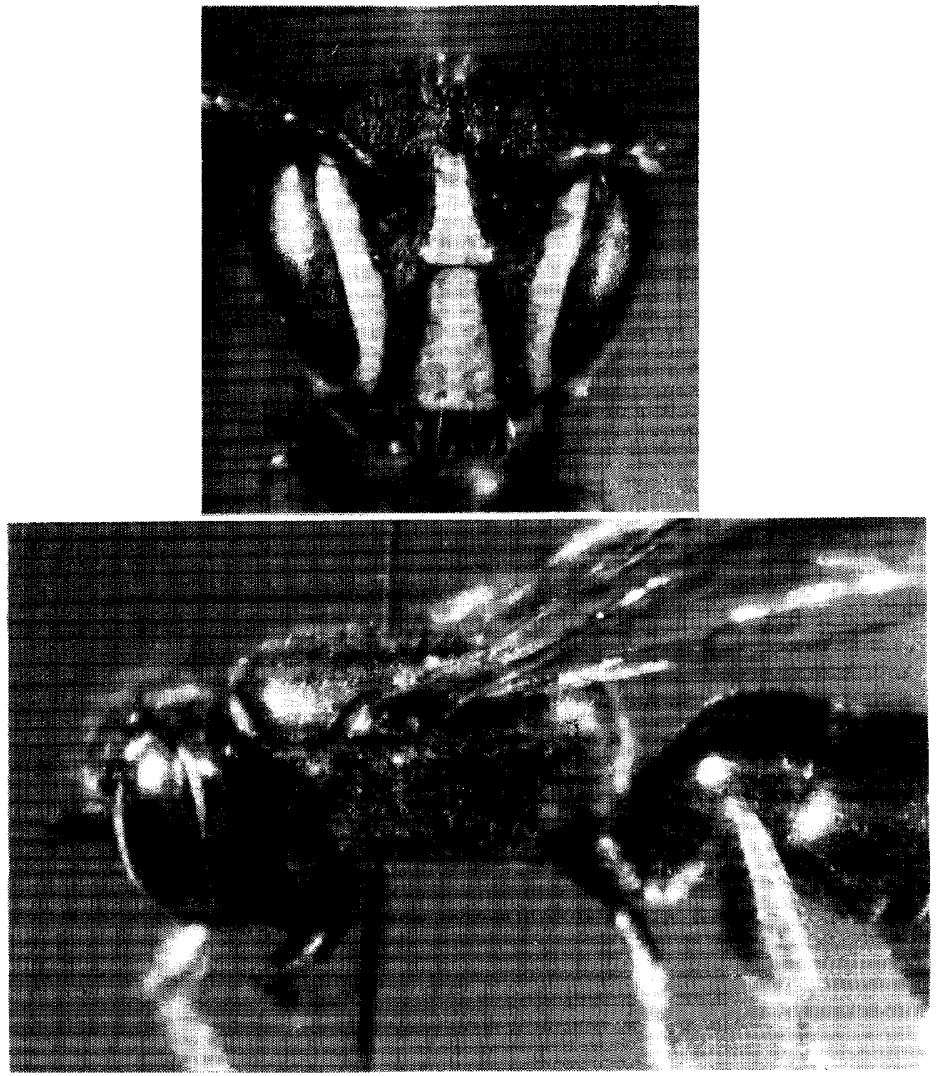

Figs. 49 (above) and 50. Palaeorhiza paracylindrica, new species, female. 49 : Head, frontal view. 50: Head, thorax and anterior part of the metasoma, lateral view. 
convex, constricted at base; median portions of 1 st and 2nd terga nearly smooth, distinctly shining, with sparse, very weak punctures; in the holotype 3rd tergum microscopically roughened.

Head and thorax dark metallic blue-green (less greenish and more bluish than in cylindrica), with following markings pale yellow : broad stripe on clypeus, broad stripe on supraclypeal area, long stripe on paraocular area along eye margin, malar space, narrow stripe on genal area along eye margin, short basal stripe on mandible, divided spot on labrum, transverse band on pronotum, a pair of very narrow, evanescent stripes on mesoscutum, mark on axilla, lateral stripe on scutellum, small lateral mark on metanotum, mark on tubercle, and three transverse evanescent marks on side of thorax below wing bases; in one specimen small yellow mark present on ocellocular space; frons without yellow marking (stripe on supraclypeal area extending above but not reaching mid ocellus in cylindrica) ; propodeal enclosure without yellow marking (a pair of stripes present on enclosure in cylindrica) ; thus, yellow markings on head and thorax less developed than in cylindrica; metasoma piceous with dark blue and purple tints (brassy in cylindrica) ; coxae, trochanters and femora piceous with slight metallic tint, apices of femora, all tibiae and tarsi pale ferruginous ; evanescent pale yellow marks on basal portions of tibiae; thus, at least tibiae and tarsi of hind legs darker than in cylindrica.

Hairs not conspicuous, whitish; hairs on apex of metasoma brown or nearly black (fulvous or nearly so in cylindrica).

Type material: Holotype female and 2 paratype females, Sigi Camp, 1,500 m, 24. II. 1939 (L. J. Toxopeus).

Distribution: W. New Guinea.

\section{(37) Palaeorhiza punctata, new species}

This is described from the holotype female and a paratype male. The new species is easily separable from the congeneric species in having the propodeal enclosure punctate latero-basally, although the punctures are not strong. We know a few more species of this species group, but the present new species is easily recognizable by the coloration of the body, which is beautiful purple or violet.

Female: Length about $8.5 \mathrm{~mm}$, fore wing about $8 \mathrm{~mm}$.

Relative head measurements: length, 32.0; width, 37.0; upper interocular distance, 19.0; width of face, 24.0; lower interocular distance, a little less than 16.0; eye length, 27.0; length of clypeus, 14.0.

Inner eye margins strongly converging below; mandible weakly tridentate ; malar space very narrow anteriorly, slightly widened posteriorly ; space between clypeus and eye narrow, but wider than nearest part of malar space; face well convex, its outline well arched as seen in profile; supraclypeal area broad, rather low, depressed above, upper limit indistinct; ocelli more or less 


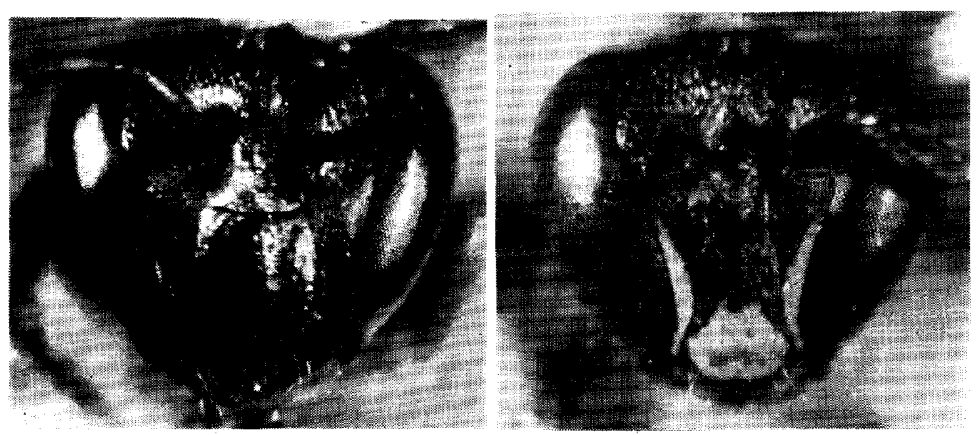

Figs. 51 (left) and 52. Palaeorhiza punctata, new species. 51: Female head, frontal view. 52: Male head, frontal view.

small, rather close together; interocellar distance slightly longer than width of lateral ocellus, slightly shorter than ocellocular distance (about $4: 5$ ), subequal to ocelloccipital distance; space behind ocelli strongly slanting. Clypeus microscopically finely tessellate and partly longitudinally lineolate, with weak, shallow punctures which are irregular in size and distribution; frons and vertex more coarsely sculptured than clypeus.

Mesoscutum very densely rugoso-punctate, punctures on median portion rather strong; scutellum flat, densely punctate, punctures larger than those on posterior portion of mesoscutum; metanotum only slightly convex, weakly, densely punctate ; propodeal enclosure large, well convex, slanting; the enclosure more finely tessellate than clypeus, rather shining, with somewhat pronounced punctures on latero-basal portions, although punctures shallow; pre- and mesoepisterna densely rugoso-punctate, punctures much weaker than those on mesoscutum.

Stigma of fore wing moderate in size; 2nd submarginal cell rather large; 1st abscissa of 2 nd submarginal cell slightly more than two-thirds of cubital vein.

Legs slender, not specially elongate ; 2nd segment of fore tarsus about as long as broad, slightly larger than 3rd, which is distinctly larger than 4th; hind tibia more or less robust, with elongate, slightly elevated area at base dorsally ; posterior spur of hind tibia normal.

Metasoma elliptical; 2nd tergum well convex and constricted at base as usual; metasomal terga distinctly and densely punctate, but punctures on 3rd roughened, shallow; impunctate apical margin of 2 nd tergum narrow, not distinct.

Head purple with green tint, especially on face; thorax distinctly metallic purple with slight green tint as seen in certain angles; metasoma shining red-purple, with slight green and blue tints as seen in certain lights; basal half of 1st tergum darkened, but still distinctly metallic. Wings slightly brownish; stigma and distal veins pale brown, basal veins including costa and subcosta 
darker brown. Legs piceous with distinct metallic purple and slightly green reflections.

Hairs sparse, not conspicuous, white or silvery; hairs on apical portion of metasoma silvery.

Male: Slightly smaller and slenderer than female.

Relative head measurements : length, 28.5; width 33.0; upper interocular distance, 17.0; width of face, 20.0 ; lower interocular distance, 10.0; eye length, 25.0; length of clypeus, 12.0 .

Agrees with description of female except as follows : Eyes large ; inner eye margins very strongly converging below; mandible bidentate ; space between clypeus and eye narrower than in female, subequal to nearest part of malar space; frons and vertex more coarsely punctate than in female; scape rather short; flagellum rather long, with 1st segment about twice as long as broad, about as long as or slightly longer than 3rd, 2nd segment broader than long; legs more elongate than in female; 1st abscissa of 2nd submarginal cell about half as long as cubital vein; 3rd sternum with a pair of weak swellings medially; 4th sternum with similar but weaker swellings; 5th sternum with golden fringe of hairs apically. Slightly more hairy than in female, with hairs on metasoma, including those on apical portion, silvery as in female.

Type material: Holotype female and paratype male, Mist Camp, 1,800 m, 1.0-13. I. 1939 (L. J. Toxopeus).

Distribution : W. New Guinea.

(38) Palaeorhiza bagudai Cheesman complex

Palaeorhiza bagudai Cheesman, 1948, Ann. Mag. Nat. Hist., (12) 1 : 321 . Male.

This species was described from the male. This is a medium-sized (about 7. $5 \mathrm{~mm}$ ), somewhat robust species. It is recognizable by the following characters.

Female : Strongly metallic blue-green, including metasoma, but often body with strong violet tint; legs also metallic; no yellow marking on any part of body. Head more or less short; inner eye margins converging below; malar space about half as long as basal width of mandible in the middle; space between clypeus and eye not specially broad, subequal to nearest part of malar space; upper swelling of supraclypeal area distinct, dilated laterally, depressed above; frons and ocellar region well convex; space behind ocelli distinctly slanting. Face including clypeus very finely lineolate-tessellate with sparse, microscopical punctures ; lower part of frons near supraclypeal area and antennae nearly smooth and impunctate, upper part near ocelli densely punctate. Mesoscutum and scutellum densely, rather strongly rugoso-punctate; the latter flat or nearly so; propodeal enclosure almost smooth, shining; mesepisternum distinctly punctate nearly as on mesoscutum. Wings more or less long; 
stigma and 2nd submarginal cell moderate in size. Fore tarsus with 2nd segment about as long as broad, about as large as 3rd. Metasomal terga smooth, highly shining, very weakly and sparsely punctate, with broad, impunctate, stnoot $\mathrm{h}$ apical margins conspicuous ; 1st tergum with dense, snow-white hair fringes on apical margin laterally ; 2nd with similar hair fringes much smaller; hairs on apical segment of metasoma whitish, but not conspicuous.

Male: Often more violet than female, especially the metasoma; clypeus, lower paraocular area, scape and fore tibia with yellow markings variable, sometimes absent. Head more elongate than female; inner eye margins strongly converging below ; malar space slightly longer than in fetnale; frons with a pair of glabrous, slightly elevated areas above antennae. Scape not elongate, slightly swollen ; flagellum long, but 1st segment small and broader than long, 2nd annular. Thorax distinctly punctate as in female, punctures on mesepisternum distinct, only slightly smaller and sparser than those on mesoscutum. Tergal hair fringes like female or slightly more developed ; hairs on apex of metasoma white as in female; metasomal sterna simple ; 5th sternum without apical fringe of curled hairs.

Remarks: The Palaeorhiza bagudai complex is a very difficult group of species which is composed of at least three species. They differ from each other by the length of malar space, the width of clypeo-ocular space, the density and size of the punctures on the thorax, and the presence or absence of the white hair-fringes on the 2 nd tergum in addition to the body coloration. We have seen about 100 specimens of this complex. The present material includes 8 specimens, which probably represent 2 species.

Spectmens examined 1 female and 1 male, Ibele Camp, 2,250 m, 7-9. XI. 1938 (L. J. Toxopeus) ; 1 female and 4 males, Baliem Camp, 1,600 m, XI. 1938 (L. J. Toxopeus) ; 1 female, Sigi Camp, 1,360 m, 20. II. 1939 (L. J. Toxopeus). Distribution : New Guinea.

\section{(39) Palaeorhiza capitata, new species}

This is described frotn the female. The new species is characteristic in having the thick head, a feature similar to Palaeorhiza subcrassiceps, new species. Thus, the new species is very close structurally to the latter, except the coloration of the body.

Female: Length about $7 \mathrm{~mm}$ or slightly smaller, with long wings.

Relative head measurements : length, 28.0 ; width, 33.5 ; upper interocular distance, 18.0 ; width of face, 22.0; lower interocular distance, 17.5 ; eye length, 23.0; length of clypeus, 11.2 .

Head rather short and broad as seen in front; head rather thick with well developed genal area, which is well convex outwardly when the head is seen from above; inner eye margins only slightly converging below ; mandible weakly tridentate ; malar space distinct, about two-thirds as long as basal 


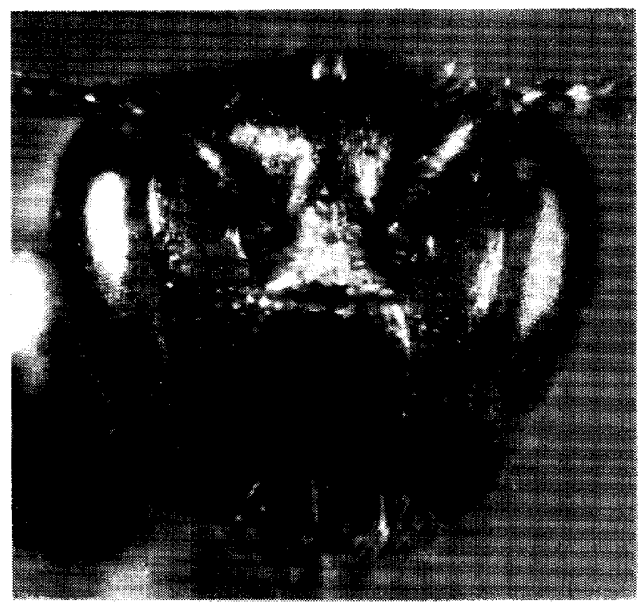

Fig. 53. Palaeorhita capitata, new species. Female head in frontal view.

width of mandible, broadened posteriorly; clypeo-ocular distance longer than nearest part of malar space; clypeus, supraclypeal area and frons well convex; upper swelling of supraclypeal area not distinct, narrowed and depressed above; ocelli small, mid ocellus smaller than lateral one ; interocellar distance slightly less than twice as broad as lateral ocellus, shorter than ocellocular distance, which is a little shorter than ocelloccipital distance; space behind ocelli well convex, posterior portion only slightly slanting. Clypeus, lower supraclypeal area and paraocular area finely lineolate-tessellate, with sparse, microscopical punctures ; frons more longitudinally lineolate, portion near ocelli punctate; space behind ocelli somewhat coarsely sculptured.

Collar of pronotum like subcrassiceps ; mesoscutum rather coarsely, densely rugoso-punctate, punctures not specially strong; punctures on mesoscutum slightly weaker than in subcrassiceps; scutellum rather flat, densely rugosopunctate, with punctures weaker than those on posterior portion of mesoscuturn; metanotum convex, densely and weakly punctate; propodeal enclosure well convex, slanting, nearly smooth and shining; pre-episternum with punctures weak, weaker and sparser than in subcrassiceps; mesepisternum smoother and more shining than in subcrassiceps, with weak, well separated punctures; lateral face of propodeum finely shagreened, with no indication of punctures.

Stigma of fore wing moderate in size ; 2nd submarginal cell large, slightly narrowed above, with 1st abscissa slightly shorter than cubital vein.

Legs more or less robust; fore basitarsus rather short; 2nd segment of fore tarsus about as long as broad, a little larger than 3rd; hind tibia with an indication of small, slightly elevated, glabrous space at base ; posterior spur of hind tibia slender, not modified.

Metasoma with 1st tergum rather large, with very weak, rather sparse punctures; 2nd tergum with median portion not specially convex, weakly and somewhat densely punctate ; 3rd tergum very densely punctate, but punctures 
very small (punctures on 3rd large, roughened and shallow in subcrassiceps); somewhat broad, slightly depressed, apical margins of 2 nd to 4 th terga not glabrous, microscopically punctate-shagreened (glabrous in subcrassiceps).

Head and thorax dark blue-green, slightly shining; clypeus clear blue-green, not blackened; no yellow marking on any part of body; legs piceous with metallic (blue-green and purple) tint; metasoma metallic but delicate in shade, primarily purple or violet, with darker shade as seen in certain lights; wings strongly brownish; veins and stigma brown; tegulae brown with blue-green tint anteriorly.

Hairs not conspicuous, dull white; no tergal hair fringe; hairs on metasoma brown including those on 5th and 6th segments.

TyPe MATERIAL: Holotype female and 1 paratype female, Sigi Camp, 1,500 m, 24. II. 1939 (L. J. Toxopeus).

Distribution: W. New Guinea.

(40) Palaeorhiza fulva Cheesman complex

This is another difficult group, composed of at least 4 or 5 species. The present material includes 5 specimens, which are separable into 2 species, as indicated below.

(40 a) Palaeorhiza fulva Cheesman

Palaeorhiza fulva Cheesman, Ann. Mag. Nat. Hist., (12) 1: 326. Female and male.

It is very probable that Cheesman did not associate the sexes correctly. The present material includes 2 female and 2 male specimens from Araucaria Camp.

Female: Length about $7 \mathrm{~mm}$.

Head, thorax, metasoma and legs fulvous, with yellow marking on head only; clypeus delicately suffused with yellow; apical 3 terga black with purple tint in one specimen; in another, 4th tergum ferruginous as in 3rd; wings distinctly brownish.

Eyes rather large, with inner margins converging below; mandible weakly tridentate; malar space about half as long as basal width of mandible in the middle, narrowed anteriorly; clypeo-ocular distance not specially long, but longer than malar space; supraclypeal area well convex, with upper swelling distinct, dilated laterally; ocelli close together; lateral ocelli rather large. Surface of clypeus shining, longitudinally very weakly lineolate-punctate; frons well convex, nearly smooth or microscopically lineolate-tessellate, with sparse, very fine punctures.

Mesoscutum and scutellum rather strongly to strongly, very densely rugosopunctate ; metanotum also densely punctate ; propodeal enclosure smooth, shining; dorsal face of propodeum lateral to enclosure also densely, strongly 
punctate; pre- and meso-episterna also densely punctate, punctures about as strong as or only slightly weaker than those on mesoscutum; lateral face of propodeum finely shagreened near anterior margin.

Fore tarsus somewhat robust, with 2nd segment a little longer than broad, a little larger than 3rd; hind tibia more or less short, somewhat thick, not modified at base dorsally; posterior spur of hind tibia normal.

First tergum rather large, smooth, distinctly shining, impunctate; 2nd like 1st but with weak, sparse punctures; 3rd like 2nd but with larger punctures; broad, impunctate, smooth, apical margins of 2nd and 3rd terga conspicuous.

Male: Agrees with description of female except as follows : Markings of head whitish; 4th and following metasomal terga blackish with purple tint. Head elongate, with long clypeus and malar space ; the latter about as long as basal width of mandible; mandible bidentate ; clypeus narrow ; clypeo-ocular distance long, about as long as malar space. Antennae with scape moderately long; flagellum rather long, with 1st segment small, about as long as broad, 2nd and 3rd broader than long, 4th a little longer than broad.

Specimens examined: 2 females and 2 males, Araucaria Camp, $800 \mathrm{~m}$, III. 1939 (L. J. Toxopeus).

\section{(40 b) Palaeorhiza sp.}

A female from Rattan Camp is superficially close to the above mentioned species but differs from it as follows :

Inner eye margins slightly more converging below; malar space shorter, slightly less than one-half of basal width of mandible; clypeo-ocular distance narrower, but longer than nearest part of malar space; clypeus and most part of supraclypeal area yellow like paraocular area ; clypeus microscopically finely reticulate, impunctate, nearly dull ; supraclypeal area similar to clypeus ; punctures on thorax weaker, especially those on pre- and meso-episterna.

Specimen examined : 1 female, Rattan Camp, 1,200 m, 5. III. 1939 (L. J . Toxopeus).

\section{(41) Palaeorhiza aenea, new species}

This is based on the holotype female and a paratype male. It is a metallic and red species. The female is distinctive in having a smooth face and long malar space. No relative of this species has been described,

Female: Length about $8 \mathrm{~mm}$, with long wings.

Relative head measurements : length, 33.0; width, 34.0; upper interocular distance, 17.0 ; width of face, 21.0 ; lower interocular distance, 15.8 ; eye length, 26.5 ; length of clypeus, 15.5 ; length of malar space, about 3.0 in the middle; width of mid ocellus, 3.0.

Head rather long as seen in front; inner eye margins slightly converging 


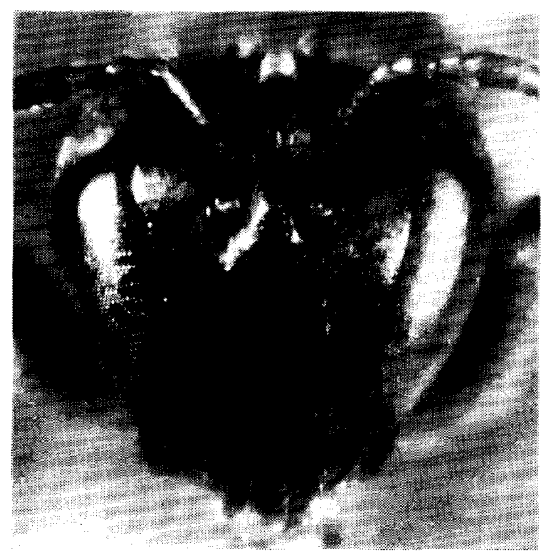

Fig. 54. Palaeorhiza aenea, $n \in w$ species. Female head in frontal view.

below; mandible weakly tridentate; malar space slightly shorter than basal width of mandible; genal area, especially lower portion, receding; face rather convex as seen in profile; supraclypeal area with upper elevation weak, depressed above, not dilated laterally; interocellar distance about equal to width of mid ocellus, slightly shorter than ocellocular distance, which is subequal to ocelloccipital distance ; space behind ocelli distinctly slanting. Supraclypeal area nearly smooth, distinctly shining, with sparse, microscopical punctures ; paraocular area nearly smooth, but very finely lineolate, with microscopical punctures similar to clypeus ; frons just below ocelli with slightly coarser punctures ; ocellocular space glabrous,

Collar of pronotum not well developed, low and thin; mesoscutum densely rugoso-punctate, punctures rather weak ; scutellum slightly convex, more coarsely punctate than posterior portion of mesoscutum; metanotum nearly flat, not specially broad, with very weak punctures in the middle; propodeal enclosure nearly triangular, slanting and not well convex, nearly smooth, shining; mesepisternum with upper portion densely punctate, punctures very weak, weaker than those on mesoscutum; precoxal carina long, strong; lateral face of propodeum densely shagreened ; this feature similar to viridiceps and subcrassiceps.

Wings with stigma large; 2nd submarginal cell large, narrowed above, with 1st abscissa about as long as cubital vein.

Legs slender; fore tarsus slender, somewhat elongate, with 2nd segment about one and half times as long as broad, 3rd longer than broad, 4th small and about as long as broad; hind tibia slender, not modified at base ; posterior spur of hind tibia slender, normal.

Metasoma long-elliptical; 1st tergum low, more or less long; 2nd well convex medially and constricted basally; metasomal terga with indication of very weak punctures ; smooth posterior margins of 4 basal terga very broad.

Head and thorax metallic blue-green except as follows: clypeus, supraclypeal area, malar space and lower portion of genal area, piceous with slight 
metallic tint; head distinctly shining in front_; propodeum with rather strong purple tint ; legs ferruginous ; metasoma red or ferruginous. without darkened part, shining, posterior margins of terga broadly subhyaline.

Hairs not conspicuous, dull white, with slight fulvous tint on side and underside of thorax; dull white hairs on propodeum not specially conspicuous ; no tergal hair fringe; hairs on apex of metasoma fulvous, shining.

Male : Slightly less than $9 \mathrm{~mm}$.

Relative head measurements : length, 35.0; width, 46.0; upper interocular distance, 17.5 ; width of face, 21.0 ; lower interocular distance, 12.5 ; eye length, 29.0; length of clypeus, 16.5 .

Agrees with description of female except as follows: eyes large with inner margins distinctly converging below ; mandible bidentate ; malar space shorter than basal width of mandible, not longer than in female; genal area strongly receding below; face flat, scarcely elevated; clypeus flat and low above, only slightly convex medio-subapically ; supraclypeal area weakly convex, with upper swelling weak; ocelli rather large; scutellum and metanotum more convex than in female. Clypeus, supraclypeal area and paraocular area finely and densely reticulate, impunctate, less smooth and less shining than in female; punctures on metasomal terga distinct, much stronger than in female. Head more metallic than in female; face, including clypeus, strongly metallic bluegreen; head with following markings pale yellow : large round mark on apical portion of clypeus, basal stripe on mandible, spot on process of labrum, and anterior stripe on scape. Thorax without yellow marking as in female. Fourth tergum and venter of metasoma with distinct purple tint. Fifth sternum with fringe of golden curled hairs apically; hairs on apex of metasoma whitish.

Type Material: Holotype female, Sigi Camp, 1,500 m, 26. II. 1939 (L. J. Toxopeus) ; paratype male, Ibele Camp, 2,250 m, 21. XI. 1938 (L. J. Toxopeus).

Distribution: W. New Guinea.

\section{(42) Palaeorhiza nana, new species}

This is described only from the holotype male. The new species may easily be known by its unique coloration. We have seen the females in the collection of the Bishop Museum, of another new species which is a close relative of the present one.

Male: More or less slender, length slightly over $6 \mathrm{~mm}$.

Relative head measurements : length, 23.0; width, 24.5; upper interocular distance, 13.5; width of face, 16.0; lower interocular distance, 8.5 ; eye length, 19.5 ; length of clypeus, 9.8 .

Head somewhat rounded in frontal view; eyes large, with inner margins strongly converging below ; mandible bidentate ; malar space linear ; clypeoocular space very narrow; upper portion of head above supraclypeal area well convex ; clypeus, lower paraocular area lateral to clypeus and lower portion of 

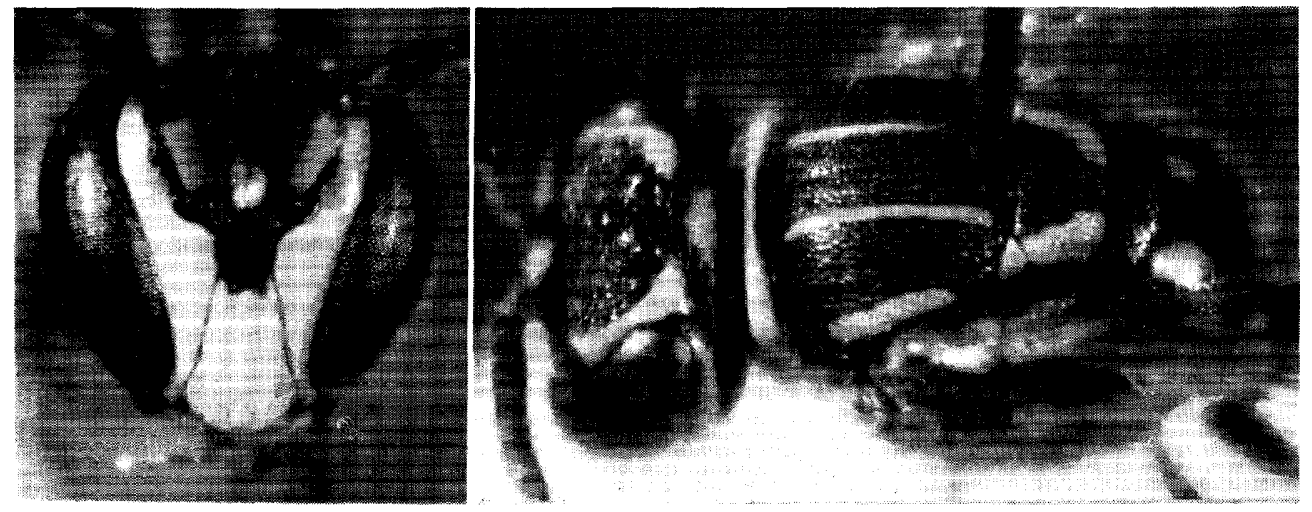

Figs, 55 (left) and 56. Palaeorhizanana, new species, male. 55: Head, frontal view. 56: Head and thorax, dorso-lateral view.

supraclypeal area flat; upper swelling of supraclypeal area low, slightly dilated laterally ; vertex well convex ; interocellar distance longer than width of lateral ocellus, slightly shorter than ocellocular distance, which is shorter than ocelloccipital distance ; genal area narrow, upper portion slightly convex ; space behind ocelli strongly slanting, somewhat concave in the middle behind. Scape short, slightly swollen, slightly excavated behind; flagellum long, more or less thick; 1st flagellar segment broader than long, 2nd ring-like, 3rd a little shorter than 4th and slightly shorter than 1st and 2nd combined.

Collar of pronotum rather thick and rounded at side, median portion slightly concave; mesoscutum densely and very weakly punctate on microscopically tessellate and somewhat shiny ground; scutellum only slightly convex, more weakly punctate than mesoscutum ; metanotum also weakly convex; propodeal enclosure almost all dorsal, nearly smooth, shining; upper portion of mesepisternum punctate like scutellum, or punctures weaker, lower portion of mesepisternum shagreened ; lateral face of propodeum finely sculptured, shining, with an indication of very small punctures.

Stigma of fore wing somewhat large; 2nd submarginal cell moderately large, with 1st abscissa about half as long as cubital vein.

Metasoma long; 1st tergum long, well convex basally, basal face steep; 2nd tergum sligthtly shorter than Ist, somewhat constricted at base; sterna unmodified.

Head and thorax metallic blue-green, with following markings or portions yellow : mandible, labrum, clypeus except upper margin, elongate mark on upper portion of supraclypeal area, mark on paraocular area extending to posterior portion of lateral ocellus, transverse mark on occipital region, long stripe on genal area along eye margin, scape, entire band on pronotum, four stripes on mesoscutum (lateral stripes shorter), triangular mark on axilla, broad lateral stripe on scutellum, a pair of round marks on propodeal enclosure, 
tubercles, large mark on upper portion of pre-episternum, transverse mark on metepisternum below wing base, and transverse mark on mesepisternum near end of pre-episternal groove ; thus, lower portion of supraclypeal area, frons, metanotum and upper portion of mesepisternum without yellow markings. Wings distinctly brownish except basal portion; tegulae pale ferruginous hyaline, with yellow spot. Legs reddened, variegated with yellow and brown. Metasoma red, only apical portion brownish.

Hairs not conspicuous ; those on thorax short, white; covering hairs on underside of thorax snow white, distinct; hairs on apex of metasoma brown or fuscous.

Type material : Holotype male, Sigi Camp, 1,500 m, 24. II. 1939 (L. J. Toxopeus).

Distribution: W. New Guinea.

\section{(43) Palaeorhiza viridiceps, new species}

This is described from 5 females. It is a medium-sized or more or less small, not robust, red species having the head only distinctly metallic. The inner eye margins are strongly converging below, and the malar space is short. No related species has become known before.

Female: Length less than $8 \mathrm{~mm}$, with long wings.

Relative head measurements : length, 29.0; width, 34.0; upper interocular distance, 16.5 ; width of face, 21.5; lower interocular distance, 14.0; eye length, 25.5 ; length of clypeus, 12.5 .

Eyes large for the size of head; inner eye margins strongly converging below, and lower half of face receding; mandible weakly tridentate; malar space short, slightly widened posteriorly; space between clypeus and eye also narrow, but slightly broader than nearest part of malar space; clypeus broadly flat, often with a weak, median, longitudinal raised line; as seen from the side of head, only supraclypeal area distinctly convex; upper portion of supraclypeal area not highly elevated, more or less broad, depressed above, upper limit not sharply indicated; frons and ocellar region well convex; postocellar distance a little shorter than ocellocular distance, which is a little shorter than ocelloccipital distance; area behind ocelli strongly slanting. Clypeus microscopically finely reticulate, nearly impunctate; paraocular area and frons similar to clypeus, but more or less lineolate longitudinally; frons with very fine, sparse punctures; space behind ocelli only slightly roughened.

Mesoscutum and scutellum very densely rugoso-punctate, but punctures small; propodeal enclosure large, well convex, nearly smooth and shining; mesepisternum with punctures close, much weaker than those on mesoscutum.

Wings with stigma large; 2nd submarginal cell moderate.

Legs more or less slender; fore tarsus slender, rather long, 2nd segment longer than broad, slightly larger than 3rd, which is also slightly longer than 


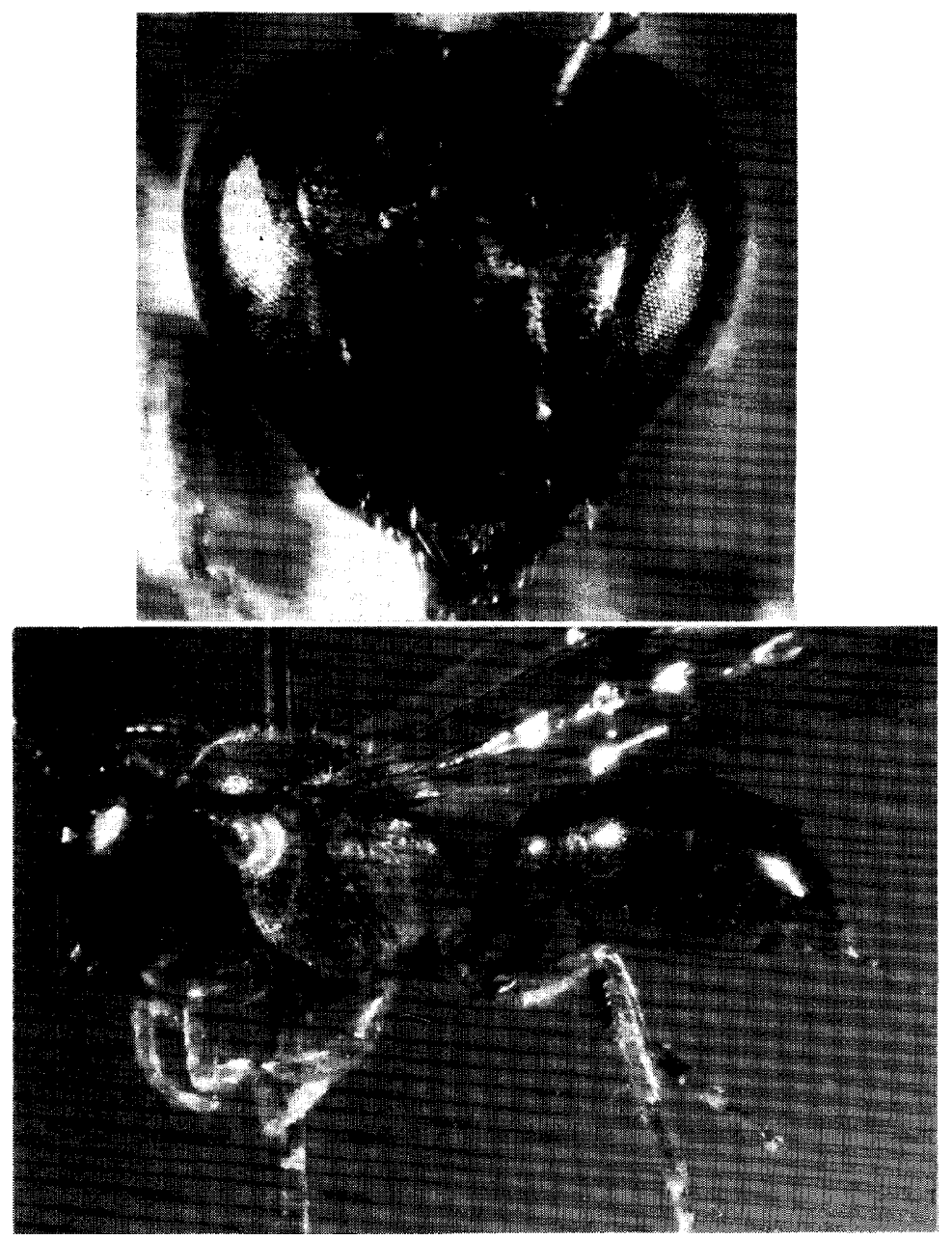

Figs. 57 (above) and 58. Palaeorhiza viridiceps, new species, female. 57: Head, frontal view. 58: Lateral view.

broad; hind tibia moderate, moderately thick at base as seen from above; posterior spur of hind tibia slightly dilated or lamellate subbasally, curved.

Metasoma with 1st tergum more or less small; 2nd tergum convex medially and slightly constricted basally; metasomal terga rather smooth, shining, with more or less dense punctures, which are weak on 1st and 2nd, roughened and shallow on 3rd; posterior margins of four basal terga broadly impunctate, smooth and ferruginous subhyaline.

Head metallic blue-green with distinct purple tint; mandibles piceous;antennae piceous, brownish in front; pronotum brownish with metallic tint dorsally; thorax red (or ferruginous), with slight metallic (blue-green and purple) tint on mesoscutum; occasionally thorax with distinct purple tint; legs 
ferruginous; metasoma red (or ferruginous), with or without metallic purple tint; no part of metasoma black or darkened. Wings distinctly brownish, basal portion paler; veins and stigma brown; tegulae ferruginous subhyaline.

Hairs not conspicuous ; hairs on head and thorax white or so; white hairs on propodeum conspicuous, dense ; no tergal fringe ; hairs on apex of metasoma reddish pale brown, not dark.

Type Material: Holotype female, Lower Mist Camp, 1,700 m, 18. I. 1939 (L. J. Toxopeus) ; paratype female, Mist Camp, 1,800 m, 10. I. 1939 (L. J. Toxopeus) ; 3 paratype females, Sigi Camp, 1,500 m, 20-27. II. 1939 (L. J. Toxopeus).

Distribution: W. New Guinea.

\section{(44) Palaeorhiza subcrassiceps, new species}

This is described from a single female only. The coloration of this species is similar to viridiceps, new species, but the structure of the head is quite distinct. In addition, the punctures on the body, especially on the mesoscutum, are stronger than in viridiceps.

Female : More or less robust, length about $7.5 \mathrm{~mm}$, with long wings.

Relative head measurements: length, 28.0; width, 32.5; upper interocular distance, 17.5 ; width of face, 21.5; lower interocular distance, 17.0; eye length, 23.0; length of clypeus, 11.0 .

Head thick; genal area well developed, convex and rounded above, scarcely receding below; inner eye margins only slightly converging below; malar space distinct, oblique, about half as long as basal width of mandible; clypeoocular distance rather long, longer than nearest part of malar space; clypeus and supraclypeal area well convex; the latter triangular in outline, upper portion slightly dilated laterally, lowered above ; frons and ocellar region well convex ; ocelli more or less small; interocellar distance a little longer than width of lateral ocellus, shorter than ocellocular distance, which is slightly shorter than ocelloccipital distance ; space just behind ocelli more or less convex (strongly slanting in viridiceps).

Collar of pronotum not thick, somewhat keel-like at side ; tnesoscutum strongly, densely rugoso-punctate; punctures progressively larger toward scutellum; scutellum also densely punctate, with punctures weaker than those on posterior portion of mesoscutum ; metanotum also densely rugoso-punctate, but punctures very weak; propodeal enclosure almost smooth, shining; mesepisternum with punctures much weaker than those on mesoscutum; lateral face of propodeum densely and very finely punctate-shagreened; this structure somewhat similar to viridiceps.

Wings with stigma large, but slightly smaller than in viridiceps; 2nd submarginal cell slightly smaller than lst, larger than in viridiceps.

Legs moderate ; fore tarsus more or less robust, 2nd segment about as long as broad, only slightly larger than 3rd; hind tibia more or less thick, not 
modified at base; posterior spur of hind tibia slender, normal.

Metasoma robust ; 1 st tergum well convex basally; metasomal terga well punctate, punctures on 1 st and 2 nd terga rather weak, those on 3 rd and 4th roughened; impunctate posterior margins of four basal terga broad, well indicated.

Head metallic blue-green, with slight purple tint as seen at certain angles; mandibles piceous; pronotum metallic (blue and purple) ; tubercles reddish brown with slight metallic shade; the rest of thorax red with slight purple and bluish tints ; legs red or ferruginous ; fore tibiae darkened medially, with metallic reflection; metasoma deep red with slight purple tinge; posterior margins of metasomal terga reddish pale brown, slightly darker than in viridiceps; no dark portion on metasoma.

Hairs not conspicuous, whitish; white dense hairs on propodeum distinct; no tergal hair fringe; hairs on apex of metasoma brownish, not specially dark. Type material: Holotype female, sigi Camp, 1,500 m, 14. II. 1939 (L. J. Toxopeus).

Distribution: W. NeW Guinea. 